\title{
MAPPING OF SEROTONIN-LIKE IMMUNOREACTIVITY IN THE LOBSTER NERVOUS SYSTEM ${ }^{1}$
}

\author{
BARBARA S. BELTZ ${ }^{2}$ AND EDWARD A. KRAVITZ
}

Neurobiology Department, Harvard Medical School, Boston, Massachusetts 02115

Received July 29, 1982; Revised October 27, 1982; Accepted October 29, 1982

\begin{abstract}
Serotonin exerts a wide range of physiological actions on many different lobster tissues. To begin the examination of the role of serotonin in lobsters at a cellular level, we have used immunohistochemical methods to search for presumptive serotonergic neurons, their central and peripheral projections, and their terminal fields of arborization. Whole mount preparations of the ventral nerve cord and various peripheral nerve structures have been used for these studies. With these tissues, more than 100 cell bodies have been found that show serotonin-like immunoreactivity. Although a few of the cell bodies are located peripherally (near the pericardial organs, a well known crustacean neurohemal organ), the vast majority are located in central ganglia. Every ganglion in the ventral nerve cord contains at least one immunoreactive cell body. The projections of many of the neurons have been traced, and we have constructed a map of the system of serotonin-immunoreactive cell bodies, fibers, and nerve endings. In addition, a dense plexus of nerve endings showing serotonin-like immunoreactivity surrounds each of the thoracic second roots in the vicinity of groups of peripheral neurosecretory neurons. These peripheral nerve plexuses originate from central neurons of the ventral nerve cord. In some cases we have been able to trace processes from particular central cell bodies directly to the peripheral nerve root plexuses; in other cases we have traced ganglionic neuropil regions to these peripheral endings.
\end{abstract}

In lobsters the monoamines serotonin and octopamine and a peptide resembling proctolin are found both in peripheral nervous tissues and within central ganglia of the ventral nerve cord. In the periphery the three substances share similar patterns of distribution throughout an extensive neurosecretory network (Sullivan et al., 1977; Livingstone et al., 1981; Schwarz et al., 1981). Plexuses of nerve endings containing these substances are found at two locations along thoracic second nerve roots of the ventral nerve cord. All three substances can bc released from these regions directly into the hemolymph, where they are likely to circulate as neurohormones able to influence the physiological state of many different lobster tissues (Maynard and Welsh, 1959; Cooke, 1966; Sullivan and Barker, 1975; Sullivan et al., 1977; Sullivan,

\footnotetext{
${ }^{1}$ We are grateful to Harvey Karten for his time and assistance in introducing us to immunohistochemical techniques. We thank Cheryl Tracy and Linda Kobierski for technical assistance, and Delores Cox and Joe Gagliardi for their help in preparing this manuscript. We also acknowledge the valuable help of our colleagues, both within and outside this department, who critiqued the manuscript. This work was supported by National Institutes of Health Grants NS-07848 and NS02253. B. S. B. was supported by a National Institutes of Health postdoctoral fellowship.

${ }^{2}$ To whom correspondence should be addressed.
}

1979; Kravitz et al., 1980). Some tissues are affected by all three substances, with differences in the details of their action. For example, on neuromuscular preparations, serotonin increases transmitter release from both excitatory and inhibitory nerve terminals and enhances the contractility of muscle fibers (Florey and Florey, 1954; Grundfest and Reuben, 1961; Dudel, 1965; Glusman and Kravitz, 1982), whereas proctolin and octopamine have the same general effect as serotonin on muscle fibers but have no effect on transmitter release (Battelle and Kravitz, 1978; Kravitz et al., 1980; Schwarz et al., 1980). In other cases one or the other of the substances has a selective action on a peripheral tissue. Thus octopamine alone enhances clotting of the hemolymph (Battelle and Kravitz, 1978), whereas serotonin and proctolin are far more effective than octopamine in increasing the strength and frequency of contraction of the heart (Cooke, 1966; Battelle and Kravitz, 1978; Florey and Rathmayer, 1978; Miller and Sullivan, 1981).

Within the central ganglia, in general, less information is available on the roles of these substances. Recent experiments have demonstrated, however, that serotonin and octopamine, when injected into freely moving lobsters, induce sustained and opposite postures. Serotonin induces a flexed and octopamine an extended posture: 
the postures result from selective activation of opposing motor programs, as determined by recording the activity of excitatory and inhibitory neurons innervating the postural flexor and extensor muscles (Livingstone et al., 1980).

In surveying the actions of these three substances on different lobster tissues, we observe a patchwork of physiological effects: sometimes the substances function in concert; sometimes they act antagonistically; occasionally only one acts on a tissue. This diversity makes it difficult to understand the role of these substances in the normal physiology of lobsters. Much of the difficulty stems from the fact that we have not thus far been able to identify and study individual nerve cells that contain and utilize one or the other of these materials as a neurotransmitter, a neurohormone, or both. (See Bishop and O'Shea (1982) for a very nice recent paper mapping sites showing proctolin-like immunoreactivity in the cockroach central nervous system.)

In the studies presented in this paper we begin to deal with this difficulty. We have used immunohistochemical procedures to locate serotonin-immunoreactive cells, processes, and endings in the lobster nervous system. These sludies have revealed a complex system of more than 100 neurons located primarily in central ganglia. Many of these cells and their processes are organized in characteristic patterns in the ganglia. In addition, the peripheral plexuses of serotonergic nerve endings found along the thoracic second nerve roots have been partially traced back to their origins in certain central neurons.

\section{Materials and Methods}

All tissues were processed for immunohistochemistry using an indirect immunofluorescence technique (Hökfelt et al., 1975), adapted by us for whole mounts or sectioned lobster tissue.

Whole mounts. Immature lobsters (Homarus americanus) 7 to $10 \mathrm{~cm}$ in length (25 to $50 \mathrm{gm}$ weight) and approximately 1 year old were used in all these experiments because their small central ganglia are readily penetrated by antibody preparations. Central ganglia, with attached thoracic second roots, were dissected in cold lobster saline of the following composition: $462 \mathrm{mM}$ $\mathrm{NaCl} ; 16 \mathrm{~mm} \mathrm{KCl} ; 26 \mathrm{~mm} \mathrm{CaCl} ; 8 \mathrm{~mm} \mathrm{MgCl} ; 11 \mathrm{~mm}$ glucose; $10 \mathrm{~mm}$ Tris; $10 \mathrm{~mm}$ maleic acid; and sufficient $\mathrm{NaOH}$ to adjust the $\mathrm{pH}$ to 7.4 (Otsuka et al., 1967; Evans et al., 1976). Dissected tissues were fixed for 12 to $36 \mathrm{hr}$ in $4 \%$ paraformaldchydc in $0.1 \mathrm{M}$ phosphate buffer $(\mathrm{pH}$ 7.4 ). In some experiments $1.37 \%$ lysine monohydrochloride and $0.214 \%$ sodium metaperiodate were added to the fixative (McLean and Nakane, 1974). These fixatives yielded identical results. After fixation, ganglia were rinsed in several changes of $0.1 \mathrm{M}$ phosphate buffer $(\mathrm{pH}$ 7.4) containing $0.3 \%$ Triton $\mathrm{X}-100$ and $0.1 \%$ sodium azide for 6 to $8 \mathrm{hr}$. Tissues were then incubated at $4^{\circ} \mathrm{C}$ in a 1:200 dilution of antiserotonin antibody (the primary antibody) for 15 to $20 \mathrm{hr}$. The antiserotonin antibodies were obtained from Immunonuclear Corp. and were generated in rabbits against a formaldehyde cross-linked serotonin-bovine serum albumin (BSA) conjugate (Steinbusch et al., 1978). Following primary antibody treat- ment, the tissues were rinsed again in phosphate/Triton $\mathrm{X}-100$ /azide for 6 to $8 \mathrm{hr}$, then incubated with the secondary antibody, which was goat antirabbit IgG labeled with fluorescein isothiocyanate (FITC). This antibody preparation was an affinity-isolated IgG produced by Boehringer Mannheim Biochemicals. Tissues were incubated in IgG-conjugated FITC at $4^{\circ} \mathrm{C}$ for 15 to $20 \mathrm{hr}$. Excess secondary antibody was removed by multiple rinses in $0.1 \mathrm{M}$ phosphate buffer ( 4 to $6 \mathrm{hr}$ total). Samples were then rinsed once in $4 \mathrm{~mm}$ sodium carbonate buffer (pH 9.5), mounted in $80 \%$ glycerol in $20 \mathrm{~mm}$ carbonate buffer, and viewed with a Zeiss ICM 405 photoinvertoscope using epifluorescent excitation. Exciter-barrier filter and reflector combination cubes were used, containing a blue excitation at 440 to $490 \mathrm{~nm}$ and a selective barrier filter at 520 to $560 \mathrm{~nm}$.

Pericardial organs and thoracic second roots were dissected from adult lobsters and processed by the same immunohistochemical technique. With these tissues, incubation and rinse times were shortened to 1 to $2 \mathrm{hr}$ because the tissues are thin and readily penetrated by the solutions used.

Sectioned material. Tissues to be sectioned were fixed in the $4 \%$ paraformaldehyde or the paraformaldehyde/ lysine/periodate (PLP) fixative used for whole mount preparations. $\Lambda \mathrm{ftcr} 12$ to $36 \mathrm{hr}$ of fixation, tissues were infiltrated with $20 \%$ sucrose in $0.1 \mathrm{M}$ phosphate buffer for 2 to $12 \mathrm{hr}$. Samples were then mounted and frozen with dry ice in preparation for cryostat sectioning. Sections (10 to $25 \mu \mathrm{m}$ ) were cut, mounted on gelatin-coated slides, and processed by the same procedure used for whole mounts, except that incubations were at room temperature and incubation times were shortened to 1 to $1.5 \mathrm{hr}$.

Specificity controls. Absorption controls were conducted by pre-incubating the antiserotonin antibody, at the working dilution, with the following antigens: (1) serotonin creatinine sulfate $(1 \mathrm{mg} / \mathrm{ml}) ;(2)$ formaldehyde cross-linked serotonin-BSA in which the BSA concentration was $300 \mu \mathrm{g} / \mathrm{ml}$, with a BSA:serotonin ratio of approximately $10: 1 \quad(\mathrm{w} / \mathrm{w}) ;(3)$ BSA (500 $\mu \mathrm{g} / \mathrm{ml})$; (4) octopamine $(1 \mathrm{mg} / \mathrm{ml})$. The serotonin - BSA conjugate was supplied by Immunonuclear Corp. and the concentrations were determined from their analysis of the compound. The antigen/antiserotonin antibody mixture was incubated at $4^{\circ} \mathrm{C}$ for 16 to $24 \mathrm{hr}$ with occasional gentle agitation, centrifuged at $100,000 \times g$ for $20 \mathrm{~min}$, and the supernatant fluid (pre-absorbed serum) was collected. In some experiments, pairs of thoracic second roots were dissected from adult lobsters, fixed with PLP for 3 to 24 $\mathrm{hr}$, and rinsed with phosphate/Triton X-100/azide. Second roots from one side of the animal were incubated with a 1:200 dilution of antiserotonin antibody, and the contralateral second roots were incubated in the preabsorbed serum. In other experiments, dissected central ganglia were incubated in pre-absorbed serum and compared with ganglia, dissected from another lobster, which were treated with a 1:200 dilution of antiserotonin antibody.

Immunonuclear Corp. has also performed cross-reactivity tests on the serotonin antisera. They found no inhibition of staining, using raphe magnus and hypothalamus as test tissues, when the sera were pre-absorbed 
with $1 \mathrm{mg} / \mathrm{ml}$ of norepinephrine, epinephrine, or dopamine.

5,7-Dihydroxytryptamine depletion experiments. The neurotoxin 5,7-dihydroxytryptamine, which selectivity destroys serotonergic endings in the lobster (Livingstone et al., 1981), was also used to test the specificity of the immunofluorescence. Immature lobsters (25 to $50 \mathrm{gm}$ ) were injected in the ventral hemolymph sinus with $4 \mathrm{mg}$ of 5,7-dihydroxytryptamine (Sigma) dissolved in $0.5 \mathrm{ml}$ of saline containing $0.5 \mathrm{mg} / \mathrm{ml}$ of L-ascorbate. Animals were injected two to three times in 5 days and were left for 2 to 4 weeks in artificial sea water tanks (Instant Ocean) before their ventral nerve cords were removed and processed for immunohistochemistry as above (see "Whole mounts").

\section{Results}

Immunohistochemistry for serotonin reproducibly stains an extensive system of cell bodies, axons, and neuropil in the central and peripheral nervous system of the lobster. In the first part of "Results" we describe this system. At the end of "Results" we present evidence concerning the specificity and sensitivity of the method.

\section{The peripheral neurosecretory system}

Previous studies have shown that the highest amounts of serotonin in the lobster nervous system are at two peripheral locations along second nerve roots of thoracic ganglia: close to a bifurcation in the proximal regions of roots in association with groups of neurosecretory neurons, and at the distal ends of roots in the pericardial organs (PCOs). In proximal regions of roots, autoradiographic studies with $\left[{ }^{3} \mathrm{H}\right]$ tryptophan and $\left[{ }^{3} \mathrm{H}\right]$ sero- tonin demonstrated widespread labeling of nerve endings in the superficial connective tissue surrounding the roots and of three small diameter nerve fibers within each root. No labeling was seen, however, of the cell bodies of the peripheral neurosecretory neurons (Livingstone et al., 1981). In the present studies, identical patterns of labeling are obtained using immunohistochemical techniques. Antiserotonin antibodies stain a dense plexus of varicosities and fine nerve processes that entirely surrounds each root in this region (Figs. 1 and 5), as well as three axons within each root (Fig. 1). No staining of the neurosecretory cell bodies is seen. When PCOs are processed for immunohistochemistry, we observe a dense plexus of nerve endings identical to that seen in the proximal regions of the second roots, but in addition an occasional 30 to $100-\mu \mathrm{m}$ structure, probably a cell body, is stained (Fig. 2). Such cell bodies are found only rarely in the PCO preparations (three PCOs out of 22 processed had one to three immunoreactive presumptive cell bodies). Several axons in the PCOs show serotonin-like immunoreactivity, but we do not know where these processes originate or terminate.

\section{The central nervous system}

There are approximately 100 neuronal cell bodies in central ganglia of the lobster that show serotonin immunoreactivity. Every ganglion in the ventral nerve cord contains at least two immunoreactive cell bodies. Among other ganglia, the brain contains approximately 34 presumptive serotonergic neurons, and each of the paired circumesophageal ganglia contains a single immunoreactive neuron. The stomatogastric, esophageal, and cardiac ganglia contain no immunoreactive neurons (E. Marder

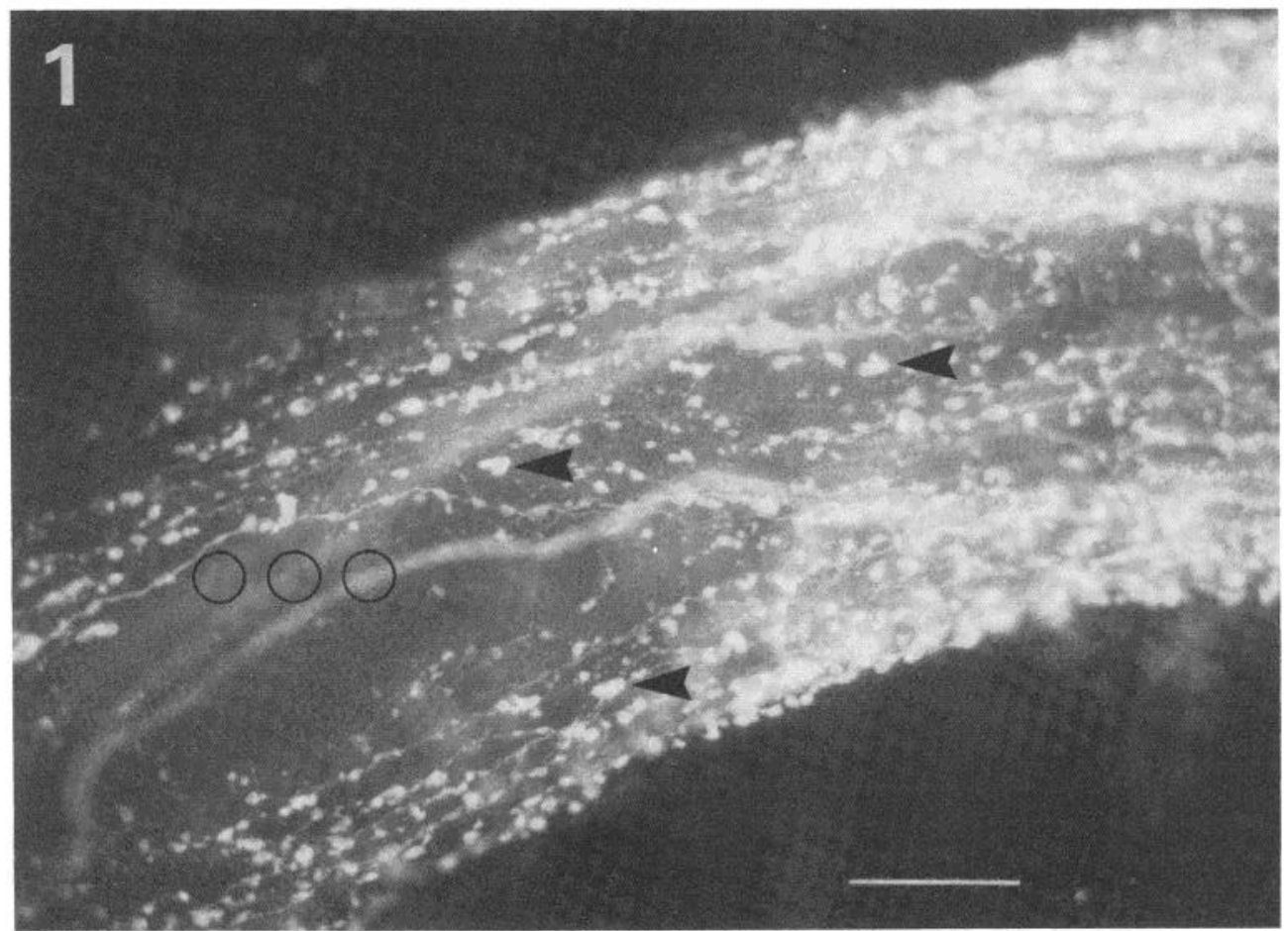

Figure 1. Whole mount immunohistochemical preparation of a thoracic second root. This photograph shows immunoreactivity in three fibers (circles) in the root and in a dense superficial plexus of varicosities (arrowheads) and fine fibers surrounding the root. Calibration bar $=50 \mu \mathrm{m}$. 


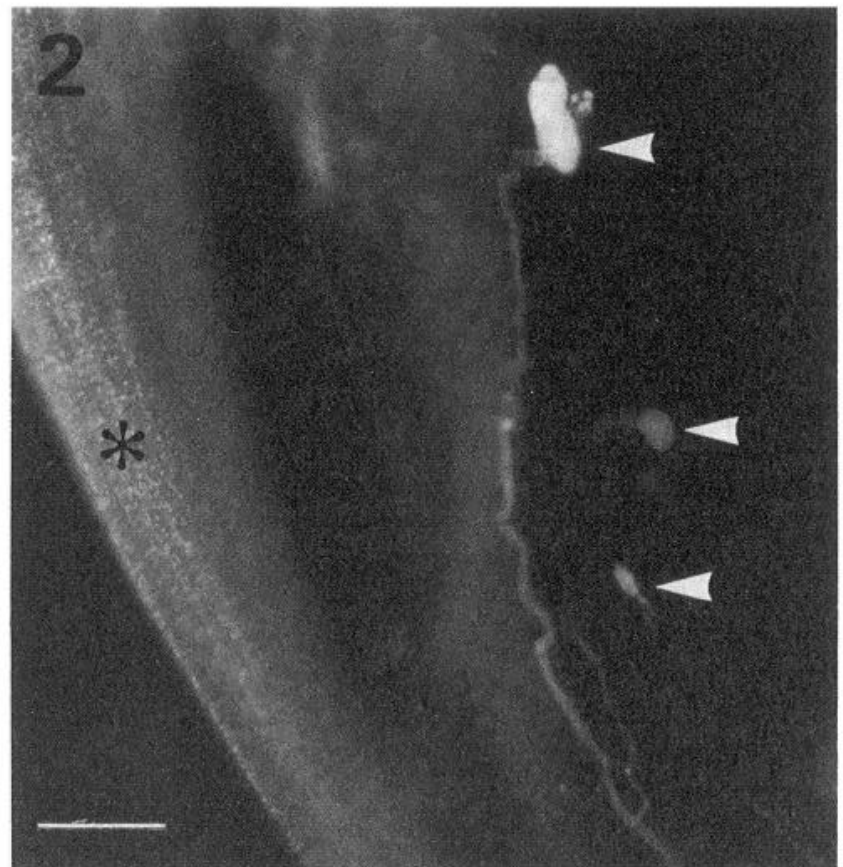

Figure 2. Photograph of part of a pericardial organ showing three immunoreactive presumptive cell bodies (arrowheads) and a superficial plexus (asterisk) like that seen surrounding the thoracic second roots (see Fig. 1). Calibration bar $=100$ $\mu \mathrm{m}$.

and B. S. Beltz, unpublished results). Figure 3 summarizes the locations of the presumptive serotonergic neurons. Many of the cells contribute processes to three bilaterally symmetrical fiber systems (described below) that run rostrocaudally through most of the length of the nerve cord. Because these whole mounts were prepared from 25- to 50-gm lobsters, the sizes quoted for cell body and fiber diameters apply only to these small animals.

The rostrocaudal immunoreactive fiber bundles (midline, central, and lateral). There are three pairs of immunoreactive fiber bundles that run longitudinally in the ventral nerve cord (Figs. 3 and 4). One pair, the midline fiber bundles (MFBs), are the most medial and, with their complement of large axons, are the most prominent of the three fiber bundles. They run the entire length of the ventral nerve cord from the subesophageal ganglion to the 6 th abdominal ganglion. At the level of the thoracic ganglia, each MFB contains one to two large axons (5 to $10 \mu \mathrm{m})$ plus two to four finer fibers; at the level of the abdominal ganglia, the fibers tend to be fewer and smaller. Although the numbers of fibers in these bundles are relatively constant as they course through thoracic ganglia, the actual population of fibers changes. Some fibers (one or two, depending on the ganglionic segment) leave, others branch off fibers in the MFB and travel to the periphery to form part of the plexus of immunoreactive varicosities that surrounds thoracic second roots (Fig. 9), and new processes join the bundle within each ganglion. In the abdominal ganglia new processes again join the bundle within each ganglion, but no fibers are seen branching off the MFBs. While we have not defined the cellular origins of all fibers in these bundles, two of the largest fibers in each thoracic MFB come from pairs of large cell bodies in the 5th thoracic and 1st abdominal ganglia (Figs. $3 c$ and 4).

The central fiber bundles (CFBs) are found only in the thoracic ganglia and connectives and contain several (three to five) very small diameter fibers (Figs. 3, $b$ and $c$, and 4). Many (possibly all) of the fibers in these bundles come from anteriorly and posteriorly directed branches from large cell bodies in the 1st through 4th thoracic ganglia. There appear to be no peripheral projections from the CFBs.

The lateral fiber bundles (LFBs), which appear discontinuous within the ganglia, extend from the subesophageal ganglion to the 6th abdominal ganglion (Figs. 3 and 4). Fibers from the LFBs join the MFBs in all of the thoracic and abdominal ganglia (see Fig. $4, b$ and $c$; fibers can be easily traced from the 1st abdominal cells and LFBs to the 5th thoracic MFBs). While it has been difficult to trace the cellular origins of many fibers in the LFBs, pairs of immunoreactive cells in the 5th thoracic and 1st abdominal ganglia do send large processes anteriorly in these bundles (Figs. $3 c$ and 4). The LFBs also are connected with the neuropil of the subesophageal, thoracic, and abdominal ganglia (Fig. 3).

The brain (supraesophageal ganglion). The brain contains approximately 34 cell bodies showing serotonin-like immunoreactivity. Most of these neurons are located anteriorly near the origin of the optic stalks in two clusters of small (20 to $30 \mu \mathrm{m}$ in diameter) cell bodies (Fig. $3 a$ ). Each cluster contains approximately 15 cell bodies that send processes posteriorly. Since these are very fine processes, they are difficult to trace over long distances. There are also two pairs of larger cell bodies (100 $\mu \mathrm{m}$ and 150 to $175 \mu \mathrm{m}$ ) lateral and posterior to the clusters of cells; their processes have not been visualized.

Circumesophageal ganglia (commissural ganglia). The circumesophageal ganglia (CEG) are paired ganglia located on the connective between the subesophageal ganglion and the brain (Fig. $3 a$ ). These ganglia contain the densest immunoreactive neuropil of any ganglion studied (Figs. $3 a$ and 8). Each ganglion also contains a single immunoreactive cell body $(60 \mu \mathrm{m})$ which sends a process anteriorly toward the brain (out of the plane of focus in Fig. 8). A single large immunoreactive fiber is found in one of the circumesophageal nerve roots, the superior esophageal nerve ( $S O N$, Fig. $3 a$ ) which joins the stomatogastric nerve. This fiber can be traced through the esophageal ganglia and into the stomatogastric ganglion (E. Marder and B. S. Beltz, unpublished results). The cell body of origin of this fiber has not been identified.

\section{The ventral nerve cord}

Subesophageal ganglion. Twenty-six small (25 to 40 $\mu \mathrm{m}$ diameter) immunoreactive cell bodies have been labeled in the subesophageal ganglion (SEG) (Fig. 3a). These cells generally appear as bilaterally paired cells or as midline clusters of three to six cells. Processes from individual cell bodies are traceable for only short distances because they are very fine. The immunoreactive neuropil of the subesophageal ganglion forms a dense ring of tissue around the circumference of the ganglion.

Thoracic ganglia. Each of the five thoracic ganglia 
conlains a pair of cell bodies containing serotonin-like immunoreactivity and a sparse neuropil region located laterally in each hemiganglion (Figs. $3, b$ and $c$, and $4, a$ and $b$ ). In most ganglia a fine process from the LFBs in the anterior ipsilateral connective can be seen ramifying to form these neuropil regions. The cell bodies from which these LFB fibers originate have not been identified. Each lateral neuropil region sends a single process out of the ipsilateral thoracic second root (Fig. 9) that forms part of the plexus of endings that surrounds the root. The other axons (one or two, depending upon the segment) that contribute to each second root plexus originate at the ipsilateral MFBs (see "The Rostrocaudal Immunoreactive Fiber Bundles" and Fig. 9). The immunoreactive cell bodies of the thoracic ganglia are large and increase in diameter as one moves from more anterior to more posterior ganglia; cell bodies in the 1st thoracic ganglion are 50 to $60 \mu \mathrm{m}$ in diameter, whereas the 5 th thoracic cell bodies are 130 to $160 \mu \mathrm{m}$ in diameter.

The patterns of organization of the immunoreactive neurons are similar in thoracic ganglia 1 to 4 , but quite different in ganglion 5 . In the four anterior thoracic ganglia, the cell bodies are located posteriorly and latcrally (Figs. 3, $b$ and $c$, and $4 a$ ). Each cell body sends a process anteriorly toward the midline where the processes cross each other (Figs. $3, b$ and $c, 4 a$, and 6). The fibers continue to travel laterally and anteriorly until they join the contralateral CFB. Each cell sends one projection anteriorly in this bundle and a second, finer diameter process posteriorly in the same bundle. In contrast, in the 5th thoracic ganglion, cell bodies arc located medially, and each sends a single, large process anteriorly and laterally rather than medially (Figs. $3 c$ and $4 b$ ). These processes join the ipsilateral LFB and travel anteriorly in the connective as part of this bundle. When they enter the 4th thoracic ganglion, they leave the LFBs, move medially, and join the ipsilateral MFBs. They then travel as part of the MFBs further anteriorly, into the 3rd thoracic ganglion. It is difficult to distinguish the fibers of these cells from other fibers of the MFBs over long distances, and, therefore, we have not been able to determine whether fibers from 5 th thoracic cell bodies are also part of the MFBs in the 1st and 2nd thoracic ganglia. As mentioned above, processes from the MFBs exit the ipsilateral thoracic second roots of the same segment. Thus the processes of the 5 th thoracic cell bodies, which are part of the MFB in the 4th and 3rd thoracic ganglia, may send branches that contribute to the nerve plexuses of the 4th and 3rd (and possibly more anterior) thoracic second roots. Also, unlike the neurons of the more anterior thoracic ganglia, the 5th thoracic cell bodies form a dense arborization of fine fibers close to the cell bodies (Fig. 7). The absence of varicosities along these fibers suggests that they may be a "dendritic," or input, region of these neurons.

The abdominal ganglia. Four different patterns of immunoreactive cell bodies (described below) are seen within the six abdominal ganglia. Posterior to the 1st abdominal ganglion, which contains three large (100 to $125 \mu \mathrm{m}$ ) cell bodies, most of the immunoreactive neurons are small ( 40 to $60 \mu \mathrm{m}$ ) with fine diameter processes (see Fig. $3 d$ ). All of the intraganglionic processes that are traceable from these cell bodies travel in an anterior direction. The MFBs and LFBs are present throughout the abdominal system, but the CFBs are not seen posterior to the 5th thoracic ganglion. There is a region on the MFBs in the center of each ganglion that has a fuzzy appearance (Fig. 10). On close inspection, this region appears to be composed of very fine unbeaded processes; this may be a synaptic input region to the MFBs. There is also a sparse neuropil region located laterally in each hemiganglion that is connected both anteriorly and posteriorly with fibers in the LFBs.

First abdominal ganglion. There are three large immunoreactive cell bodies in the 1st abdominal ganglion (Figs. $3 c$ and $4 c)$. These include a pair of large $(100 \mu \mathrm{m}$ diameter) cells positioned anterolaterally in the ganglion, each of which sends a process anteriorly in the ipsilateral LFB. Branches from these processes project out the ipsilateral second and third roots of the 5th thoracic ganglion (Fig. 3c). When the primary projections from these cells reach the 5th thoracic ganglion, they travel medially and join the ipsilateral MFB. The same axonal projection pattern is followed by processes of the pair of immunoreactive neurons in the 5th thoracic ganglion. When 1st abdominal fibers within the MFBs reach the 4th thoracic ganglion, they send a branch out the ipsilateral second root. The same 1 st abdominal fibers continue to travel anteriorly, but we do not know if they continue to send branches out the second roots of more anterior ganglia. The third unpaired cell $(125 \mu \mathrm{m}$ diameter $)$ is found in a medial position in the ganglion and sends a single, small diameter process anteriorly. Because this process is fine, we have not been able to follow it after it leaves the ganglion.

Second to fourth abdominal ganglia. Each of these ganglia contains two pairs of small $(40$ to $60 \mu \mathrm{m}) \mathrm{immu}-$ noreactive neurons. One pair is located anteromedially and the other pair in a more lateral and posterior position (Fig. $3 d$ ). In the 2nd abdominal ganglion, the more anterior paired cells send fine diameter processes into the anterior connectives that join the ipsilateral LFBs (Fig. $3 d)$. The origin of the other fibers in the LFBs at this ganglionic level is not known. We have had difficulty tracing the fibers of the other immunoreactive paired cells in these ganglia, but we have been able to observe that they project anteriorly.

Fifth abdominal ganglion. The 5th abdominal ganglion, like the 1st, contains three immunoreactive cell bodies: two paired neurons and a large, unpaired medial neuron ( $120 \mu \mathrm{m}$ diameter) (Fig. $3 d$ ). The paired cells are much smaller $(50 \mu \mathrm{m}$ diameter) than those of the 1 st abdominal ganglion. Processes from the paired cells travel into the anterior connective, where they join the ipsilateral LFBs (Fig. 3d). The medial unpaired neuron sends a single process anteriorly that divides within the ganglion; each branch then travels anteriorly in the connective (Fig. $3 d$ ). We do not know if these fibers join the major immunoreactive fiber bundles.

Sixth abdominal ganglion. With some variation by one or two cells in different preparations, there are approximately seven immunoreactive neurons in the 6th abdominal ganglion (Fig. 3d). Five cells (approximately 40 to $50 \mu \mathrm{m}$ in diameter) are found in an anteromedial position in the ganglion. Two larger (60 to $70 \mu \mathrm{m}$ diameter) unpaired immunoreactive cells are located on the 


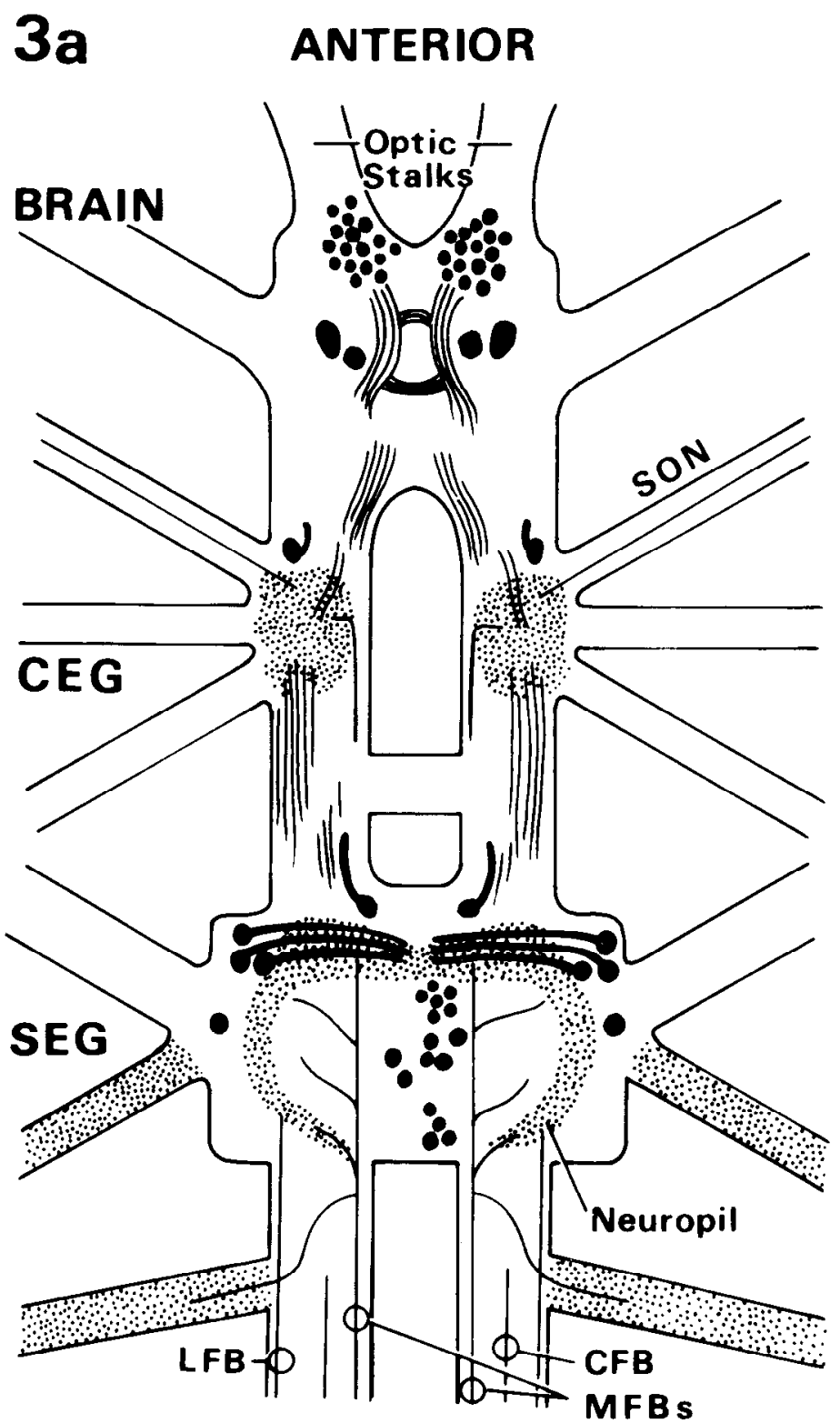

POSTERIOR 3b ANTERIOR

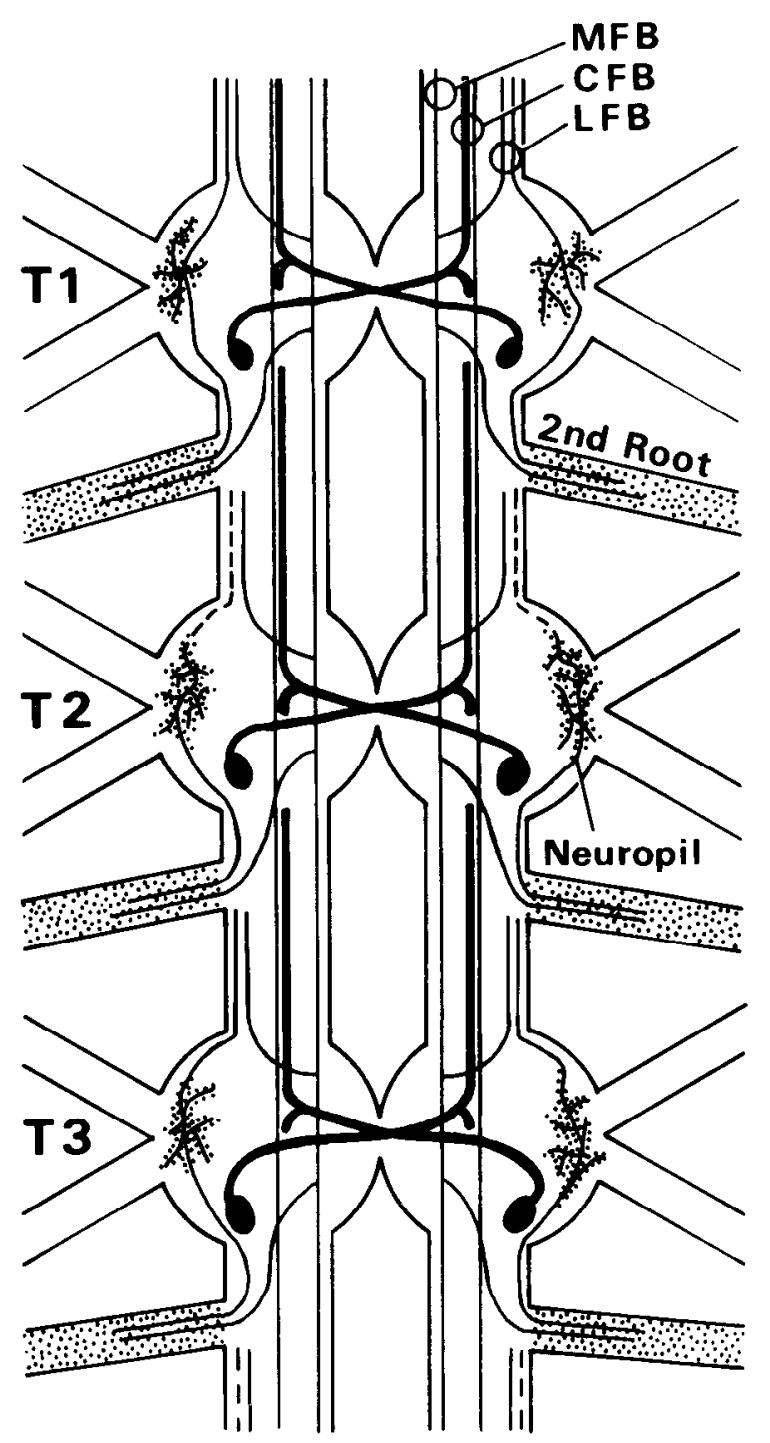

POSTERIOR

Figure 3. Schematic diagrams of the immunoreactive cell bodies, fibers, and neuropil of the ventral nerve cord. This is a composite drawing of whole mount preparations of 10 ventral nerve cords. In general, major details are similar in the different preparations. When differences are seen they are in the clarity of the preparations and, therefore, in the ability to trace fine processes. $a$ to $d$ represent continuous lengths of ventral nerve cord. Cell bodies are drawn as large, solid, round or elongate circles. Heavy black lines represent immunoreactive fibers that have been traced to their cell bodies of origin. Fine lines indicate immunoreactive fibers that have not been connected with cell bodies. Each of the fine lines of the LFBs, CFBs, and MFBs represents several fibers. Dashed lines ( $b$ and $c$ ) indicate fibers that have not been directly visualized in these immunohistochemical preparations, but which we believe exist because the patterns of staining are similar from ganglion to ganglion. Stippled regions represent fine processes and varicosities of neuropil and plexus regions. In some areas the drawing has been simplified for the sake of clarity. The text should, therefore, be used in conjunction with these drawings to provide additional details. $a$, The brain, circumesophageal ganglia $(C E G)$ and subesophageal ganglion $(S E G)$. Two pairs of roots of the SEG are surrounded by plexuses of fine processes and varicosities that are analagous to the thoracic second roots. SON, supraesophageal nerve. $b$, The 1st $(T 1)$, 2nd (T2), and 3rd (T3) thoracic ganglia. Each second root receives a process from the ipsilateral MFB and a process from the ipsilateral neuropil region of the same ganglion (see also Fig. 9). c, The 4th (T4) and 5th (T5) thoracic ganglia and 1st abdominal ganglion $(A 1)$. This is the same region of the nerve cord that appears in Fig. $4, a$ to $c$. Note that in $A 1$ there is a stippled region on the MFB. In the actual whole mount preparations, this region shows fine, unbeaded processes; this may be an input region to the MFB. $d$, Abdominal ganglia 2 to 6 (A2 to A6). Each ganglion contains lateral neuropil regions and (stippled) central regions representing fine, unbeaded processes on the MFB. 


\section{3c ANTERIOR}

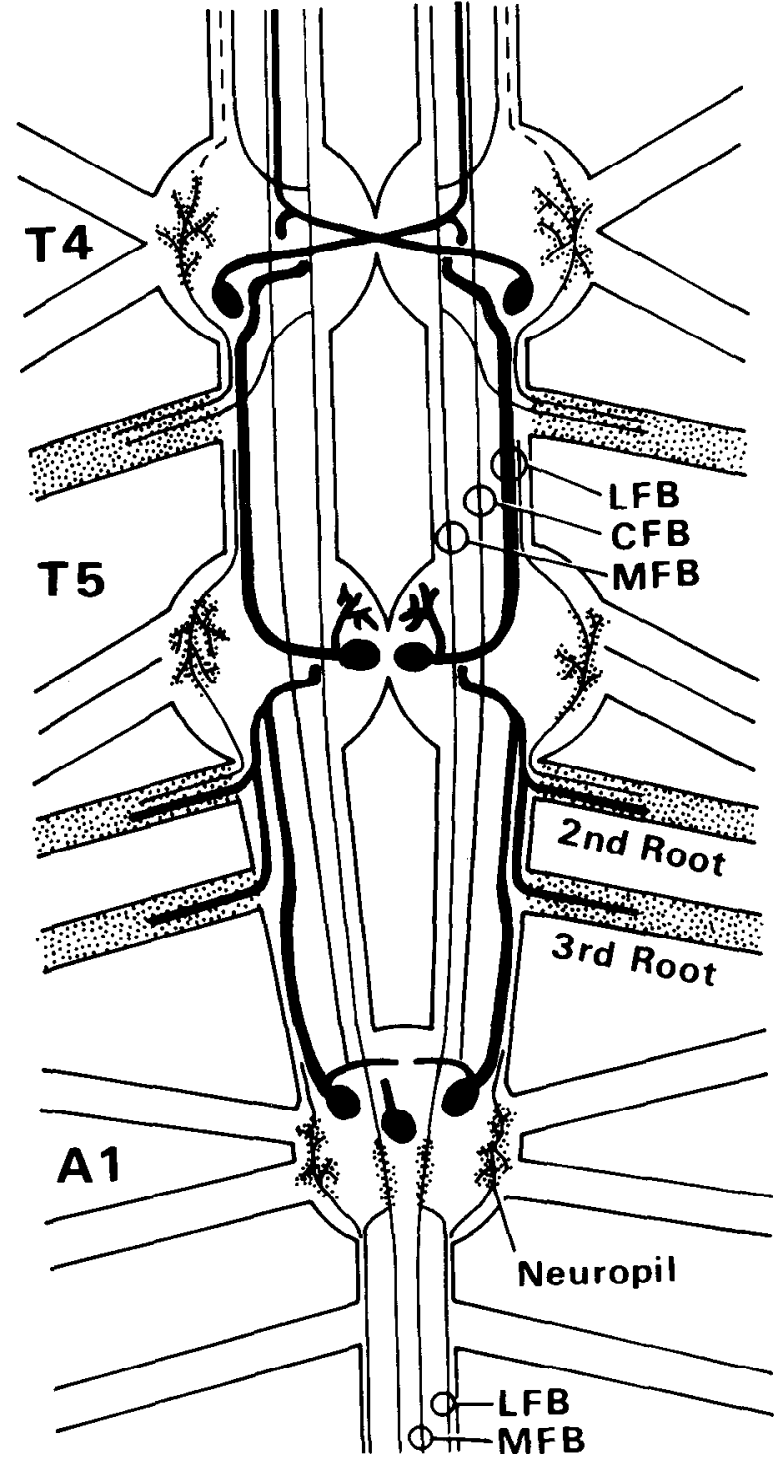

POSTERIOR 3d ANTERIOR

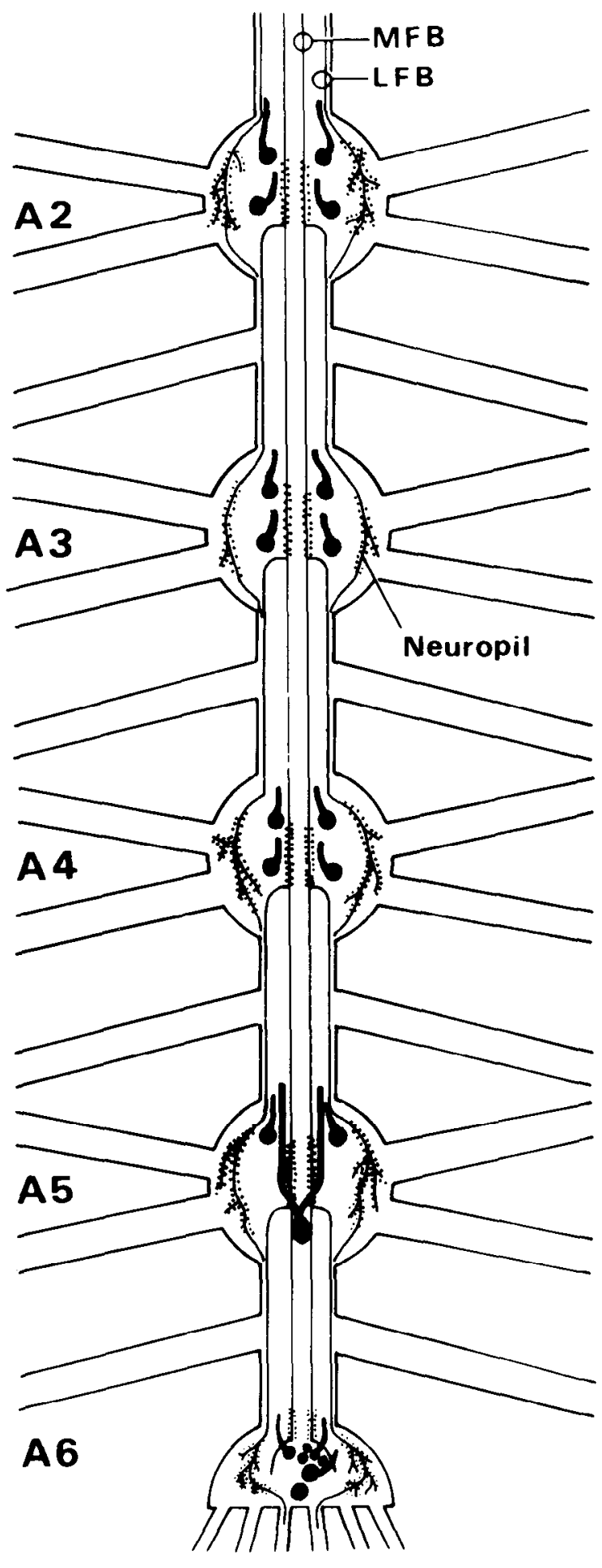

POSTERIOR

Figure 3 continued 


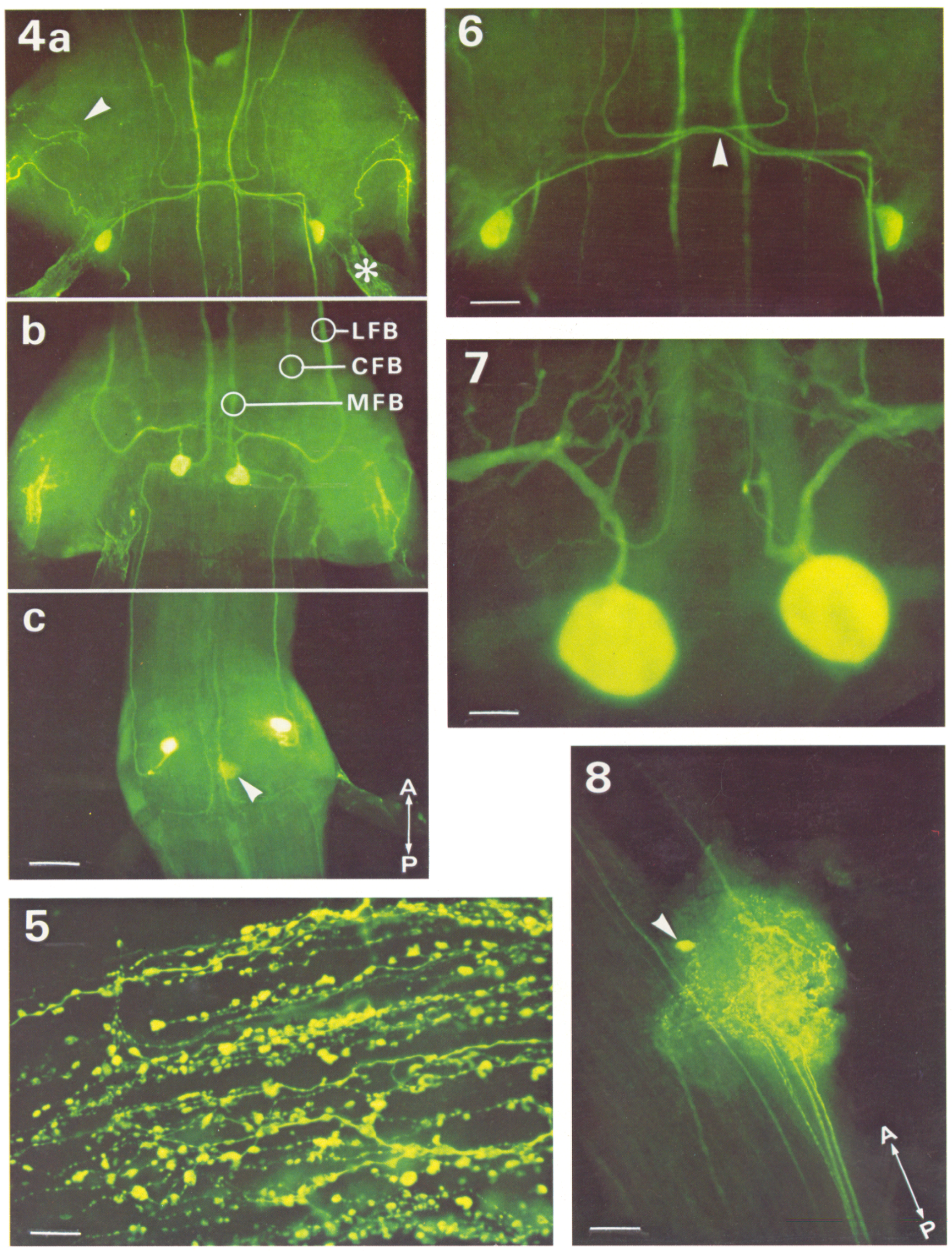


ganglionic midline: one in the center, the other at the posterior edge of this ganglion (Fig. $3 d$ ). In this ganglion, unlike the other abdominal ganglia, immunoreactive fibers can be traced from the LFBs out two posterior medial nerve roots running to peripheral tissues.

Other ganglia. The stomatogastric, esophageal, and cardiac ganglia have been examined in Homarus americanus, Panulirus interruptus, and Cancer borealis (E. Marder and B. S. Beltz, unpublished results). In Homarus, preliminary results show no cell bodies staining, but immunoreactive fibers of unknown origin are present in each of these ganglia; in addition, the stomatogastric ganglion contains a dense, stained neuropil.

\section{Sensitivity of the whole mount technique}

Control studies. The experimental results with whole mount preparations are highly reproducible. However, since the ability of antibodies to penetrate large pieces of tissue is a concern, even in the presence of a detergent (Triton X-100), representative ganglia from immature lobsters were sectioned in a cryostat prior to immunohistochemical processing. Twenty-micron sections were cut and processed as outlined under "Materials and Methods." Sections were examined, and we recorded the numbers of immunoreactive cell bodies, their sizes, positions, and projections. The sectioned and reconstructed

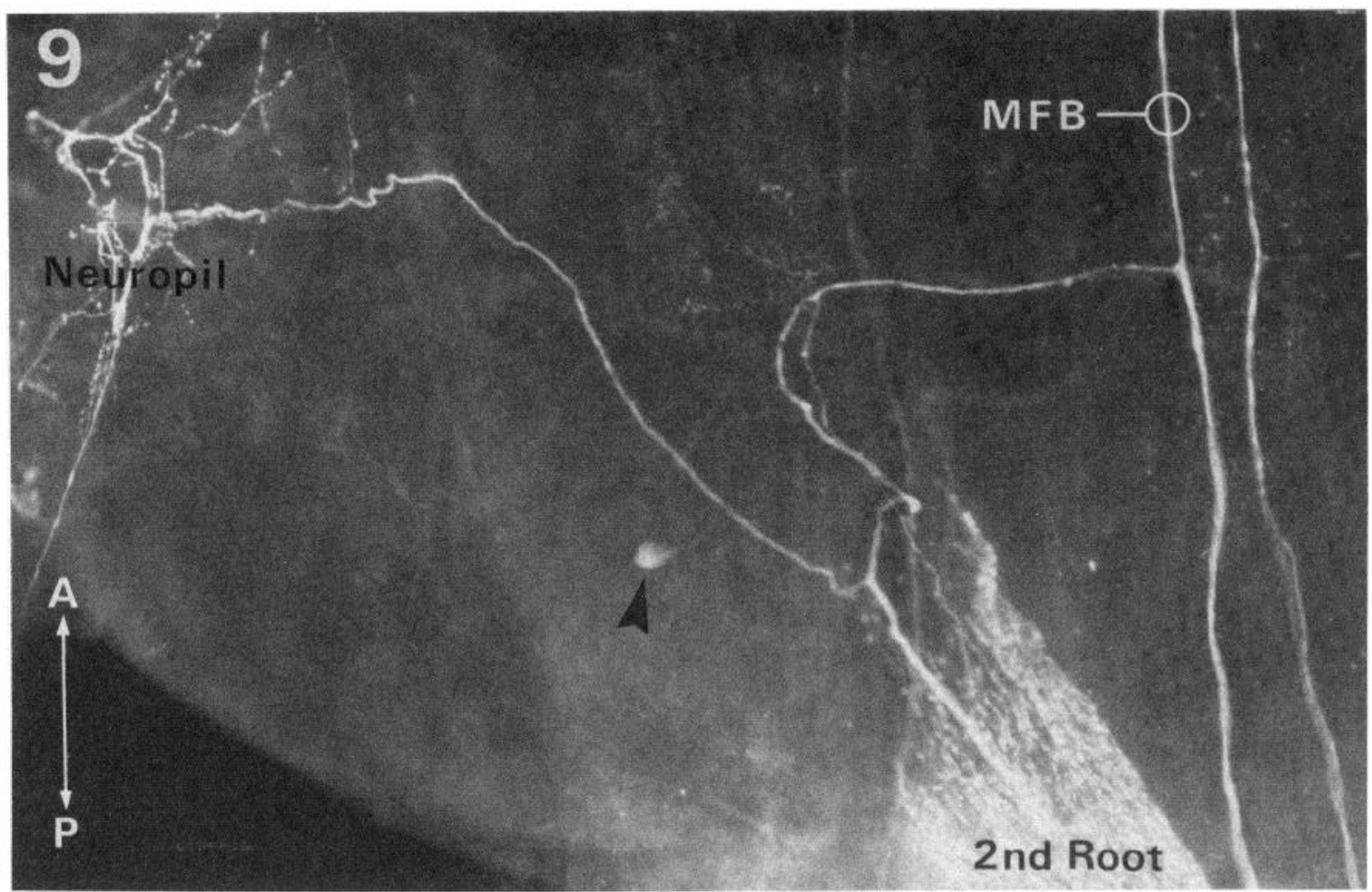

Figure 9. Part of a 2nd thoracic ganglion, showing fibers projecting out of the thoracic second root. One fiber comes from the lateral neuropil and another from the MFB. An arrowhead points to one of the paired 2nd thoracic cell bodies. Calibration bar $=100 \mu \mathrm{m}$.

Figure 4. Photographs of the 4th thoracic $(a)$, 5th thoracic $(b)$, and 1st abdominal $(c)$ ganglia following whole mount immunohistochemical processing. Photographs of the connectives linking the ganglia together have been removed for this illustration. Fiber bundles are, however, continuous from one ganglion to the next in actual preparations. These photographs can be compared with Fig. $3 c$, the schematic diagram of the same region. Calibration bar $=240 \mu \mathrm{m}$. $a$, The 4 th thoracic ganglion contains a pair of lateral cell bodies, each of which sends a process anteromedially (for enlargement, see Fig. 6). Each of these processes eventually joins the contralateral central fiber bundle. The arrowhead indicates a lateral neuropil region. The asterisk is over one of the second roots (see Fig. 5). $b$, The 5th thoracic ganglion. The paired cells are located medially in this ganglion. Each has a region of fine, unbeaded fibers branching off the main cell process (for enlargement of this area in a different preparation, see Fig. 7). $c$, The 1st abdominal ganglion. Processes of the paired cells project anterolaterally, as do those of the 5th thoracic paired cells $(b)$. Lateral neuropil regions, present in each of the abdominal ganglia, are out of the focus plane of this photograph. The arrowhead points out the third, unpaired cell.

Figure 5. Part of the plexus of varicosities and fine fibers found surrounding each thoracic second root. Calibration bar $=30$ $\mu \mathrm{m}$.

Figure 6. Enlargement of cell bodies and processes of the 4th thoracic ganglion shown in Figure 4a. The fibers of these cells project anteromedially and decussate in the midline of the ganglion (arrowhead). Calibration bar $=150 \mu \mathrm{m}$.

Figure 7. The 5th thoracic cell bodies and fine unbeaded processes branching off the main axon. This photograph is from a different preparation than that shown in Figure $4 b$. Calibration bar $=75 \mu \mathrm{m}$.

Figure 8. The circumesophageal ganglion. A single cell body is shown at the arrowhead. This ganglion also shows a dense neuropil region and darkly staining fibers in both the posterior and anterior connectives. Calibration bar $=150 \mu \mathrm{m}$. 
ganglia (subesophageal, 2nd to 5th thoracic, and 1st abdominal) were then compared with whole mount preparations (Fig. 11). In all cases, sectioned material yielded results similar to those of the whole mounts. This suggests that processing the tissues as whole mounts was giving us a realistic picture of the organization of these ganglia. Occasionally faintly stained cells were seen in sections that had not been seen in whole mount preparations (Fig. 11a); however, these cells were few in number and were not reliably seen in repeated experiments.

In several experiments, ganglia were incubated in tryptophan $\left(10^{-7} \mathrm{M}\right)$, serotonin $\left(10^{-8} \mathrm{M}\right)$, or colchicine $(7 \mathrm{~mm})$ for $3 \mathrm{hr}$ prior to fixation in an attempt to increase serotonin levels in the ganglia (Livingstone et al., 1980) and thereby reveal other immunoreactive cells, processes, or nerve endings. Following these incubations, no additional immunoreactive cells were identified, and the pattern of organization of neuropil regions was unchanged. The neurosecretory cell bodies in the thoracic second roots also remained unstained.

\section{Controls for age of animals}

In most of the experiments in our laboratory we use adult (5- to 6-year-old, $0.5 \mathrm{~kg}$ ) lobsters. In all of the experiments in these studies, however, we used younger (approximately 1-year-old) and smaller (25 to $50 \mathrm{gm}$ ) lobsters. In order to assure ourselves that the patterns of neuronal labeling were similar, at least in some ganglia, in immature and adult animals, we fixed, sectioned, and examined 5th thoracic and 1st abdominal ganglia of adult animals. The numbers and positions of immunoreactive cell bodies were the same in young and adult animals
(Fig. 12a), and the fiber bundles found in the immature lobsters were also present in adults (Fig. 12b). The main difference between ganglia from the two groups of animals was in the density and size of the thoracic neuropil. In ganglia from young animals, thoracic neuropil regions were present but sparse (Figs. $4, a$ and $b$ and 9). In an adult 5 th thoracic ganglion, neuropil regions were large in diameter $(800 \mu \mathrm{m})$ and the region stained was densely filled with fine processes and varicosities (Fig. 12c). This increase in size and density of the neuropil is much greater than one might expect by simply comparing overall size increases of the whole ganglia between immature and adult animals.

\section{Specificity of the immunofluorescence}

Control studies. In the studies reported in this paper, identical results were obtained with two lots of serotonin antisera raised in different rabbits. In addition to the specificity tests performed by Immunonuclear Corp. (see "Materials and Methods"), we examined the specificity of the staining by pre-absorption of antisera with serotonin, a serotonin-BSA conjugate, BSA, and octopamine (see "Materials and Methods"). For these experiments pairs of second roots (proximal bifurcation regions) were used: a thoracic second root from one side of the animal was treated with the normal 1:200 dilution of antiserum and served as the control for the experimental contralateral root which was treated with pre-absorbed serum. A control incubation is shown in Figure $13 a$. No fluorescence is seen in second roots after pre-absorption of serum with the serotonin-BSA conjugate (Fig. 13b),

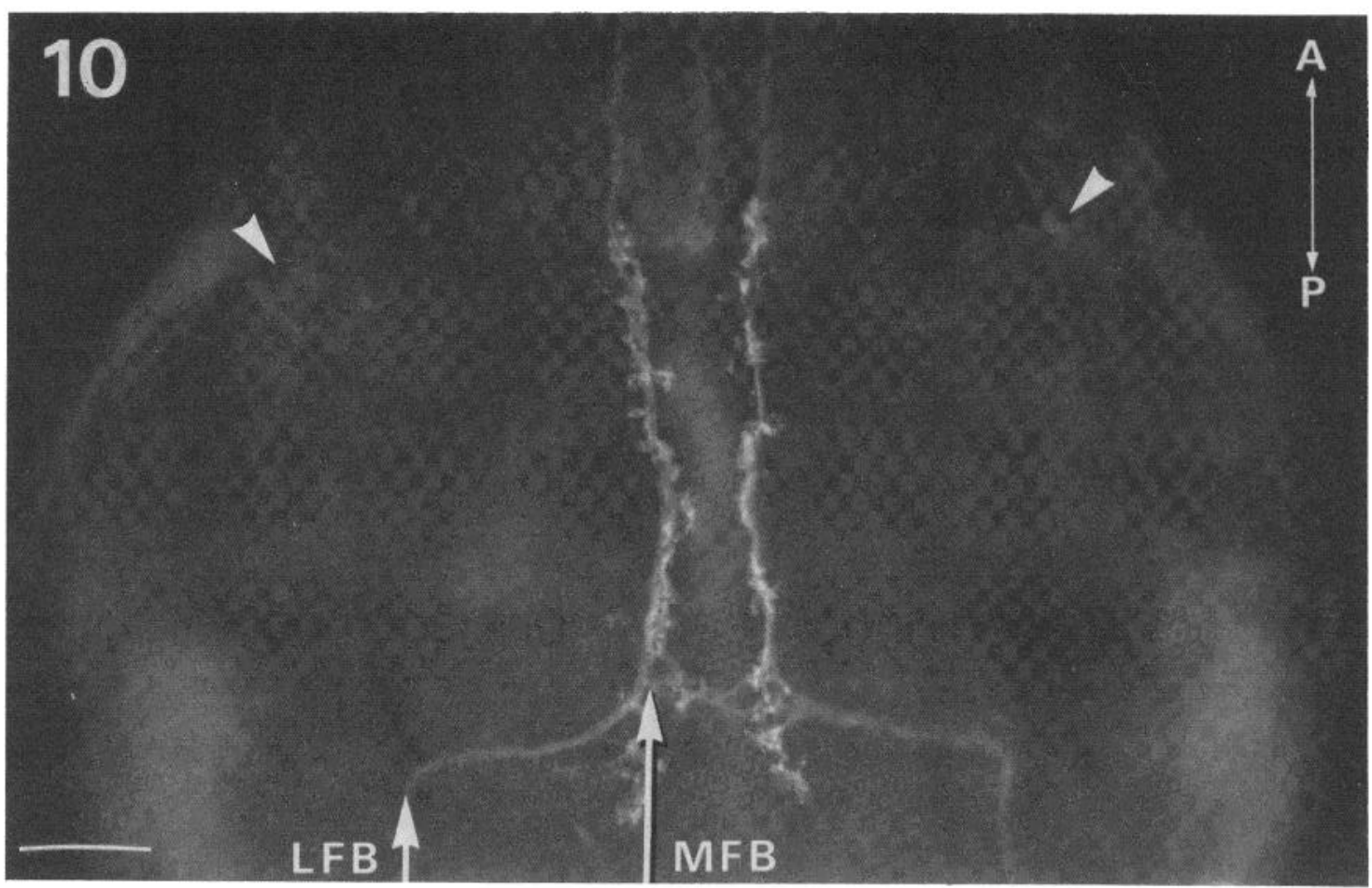

Figure 10. MFBs of the 5th abdominal ganglion. A fuzzy, unbeaded region can be seen that is composed of very fine fibers. A process in the $L F B$ on each side travels anteriorly, and then medially, to join the MFBs. Arrowheads point to anterior parts of the lateral neuropil regions. Further details of this region are out of the focus plane of this photograph. Cell bodies in this ganglion are not shown in this picture. Calibration bar $=100 \mu \mathrm{m}$. 

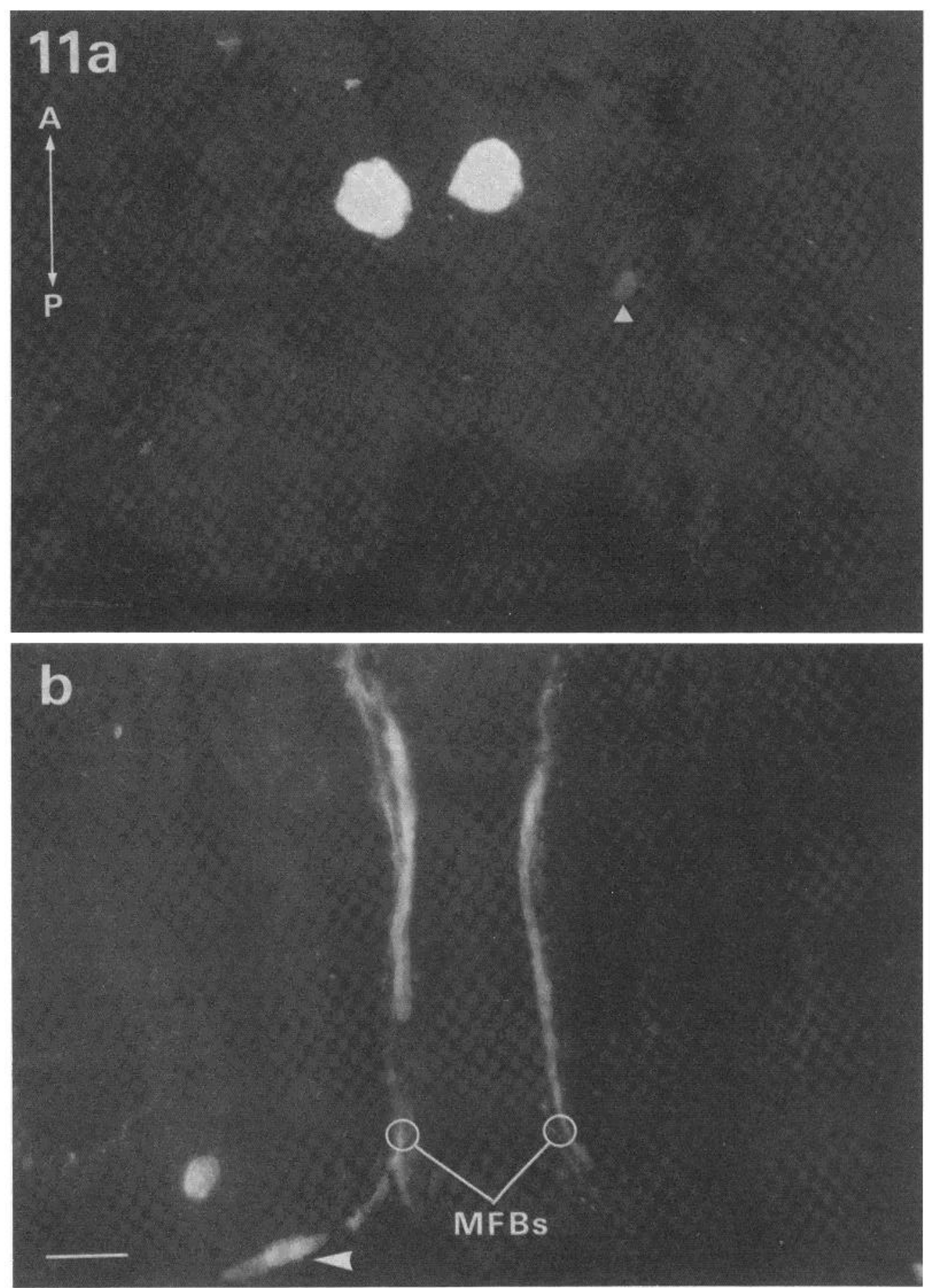

Figure 11. Photographs of $20-\mu \mathrm{m}$ sections of a 5 th thoracic ganglion from an immature lobster processed for immunohistochemistry. These pictures show immunoreactive structures similar to those seen in tissues prepared as whole mounts (see Fig. $4 b)$. $a$, Section through the ventral part of 5 th thoracic ganglion. Large immunoreactive paired cells are positioned amidst a cluster of unstained cells. Arrowhead points out a small, faintly stained cell that has not been seen reproducibly in other preparations. Calibration bar $=100 \mu \mathrm{m}$. $b$, Section through the dorsal part of a 5 th thoracic ganglion. Immunoreactive fiber bundles are seen in sectioned ganglia in similar positions to those seen in whole mount preparations. An arrowhead points to a LFB traveling medially to join the ipsilateral MFB. The identity of the immunoreactive, round structure above and to the right of the calibration bar is not known; we expect that it is not a cell body because cell bodies are generally not found on the dorsal side of these ganglia. This structure also showed no neuronal processes. Calibration bar $=50 \mu \mathrm{m}$. 

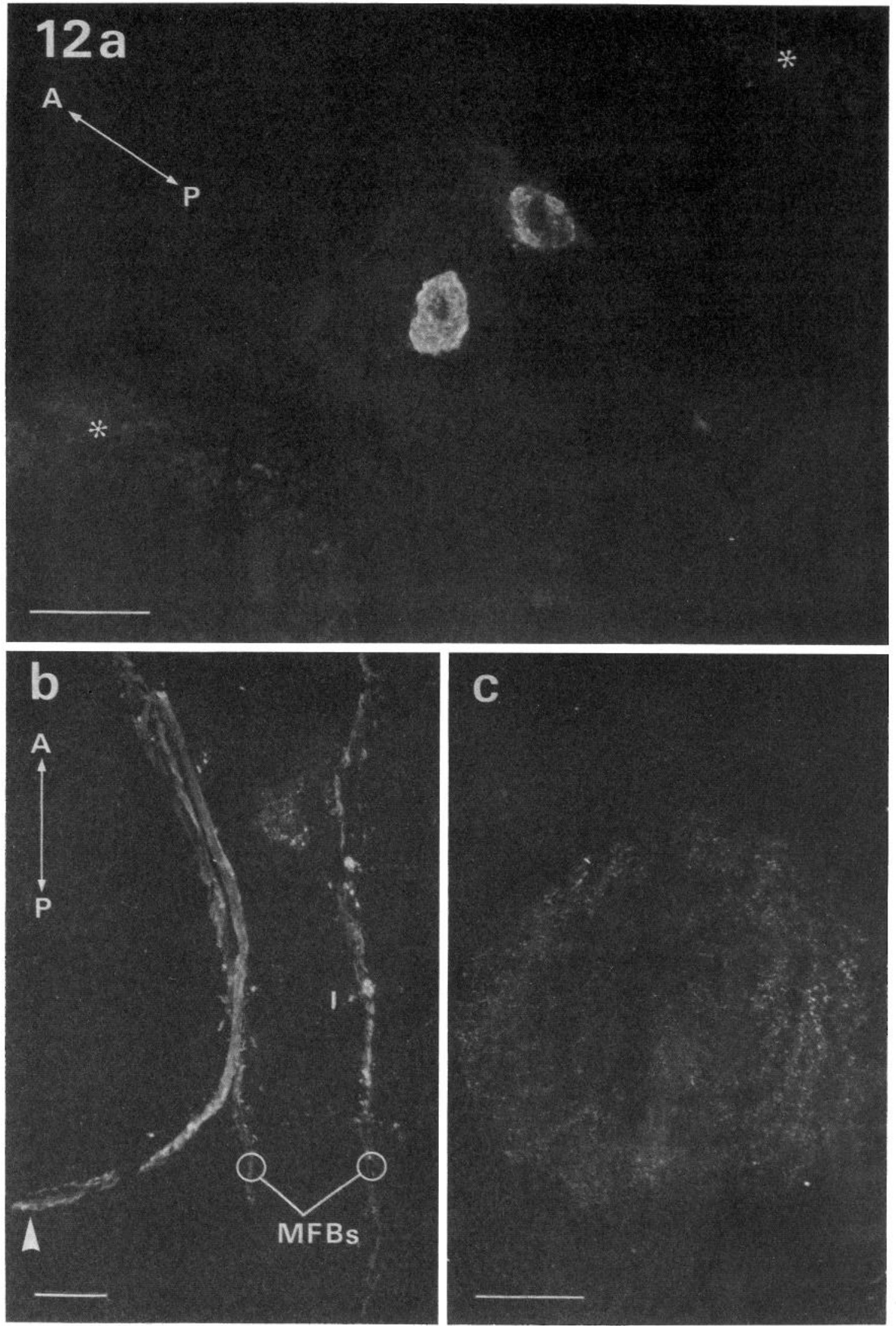

Figure 12. Photographs of $20-\mu \mathrm{m}$ sections through an adult 5 th thoracic ganglion processed for immunohistochemistry. $a$, A ventral section, showing the paired cells amidst unstained cells. The asterisks are on the lateral neuropil regions, one of which is shown more completely in $c$. Compare this photograph to Figures $4 b$ (5th thoracic whole mount, immature lobster) and $11 a$ (sectioned 5th thoracic, immature lobster). Calibration bar $=200 \mu \mathrm{m}$. $b$, Section through the dorsal part of the ganglion, showing a fiber from the lateral fiber bundle (arrowhead) projecting medially to join the ipsilateral MFB. Compare to Figures $4 b$ and $11 b$. Calibration bar $=100 \mu \mathrm{m}$. $c$, One of the two lateral neuropil regions found on either side of the paired cells (see $a$ ). Compare to the relatively sparse lateral neuropil found in ganglia of immature lobsters (see Figs. 4, $a$ and $b$, and 9 ). Calibration bar $=200$ $\mu \mathrm{m}$. 

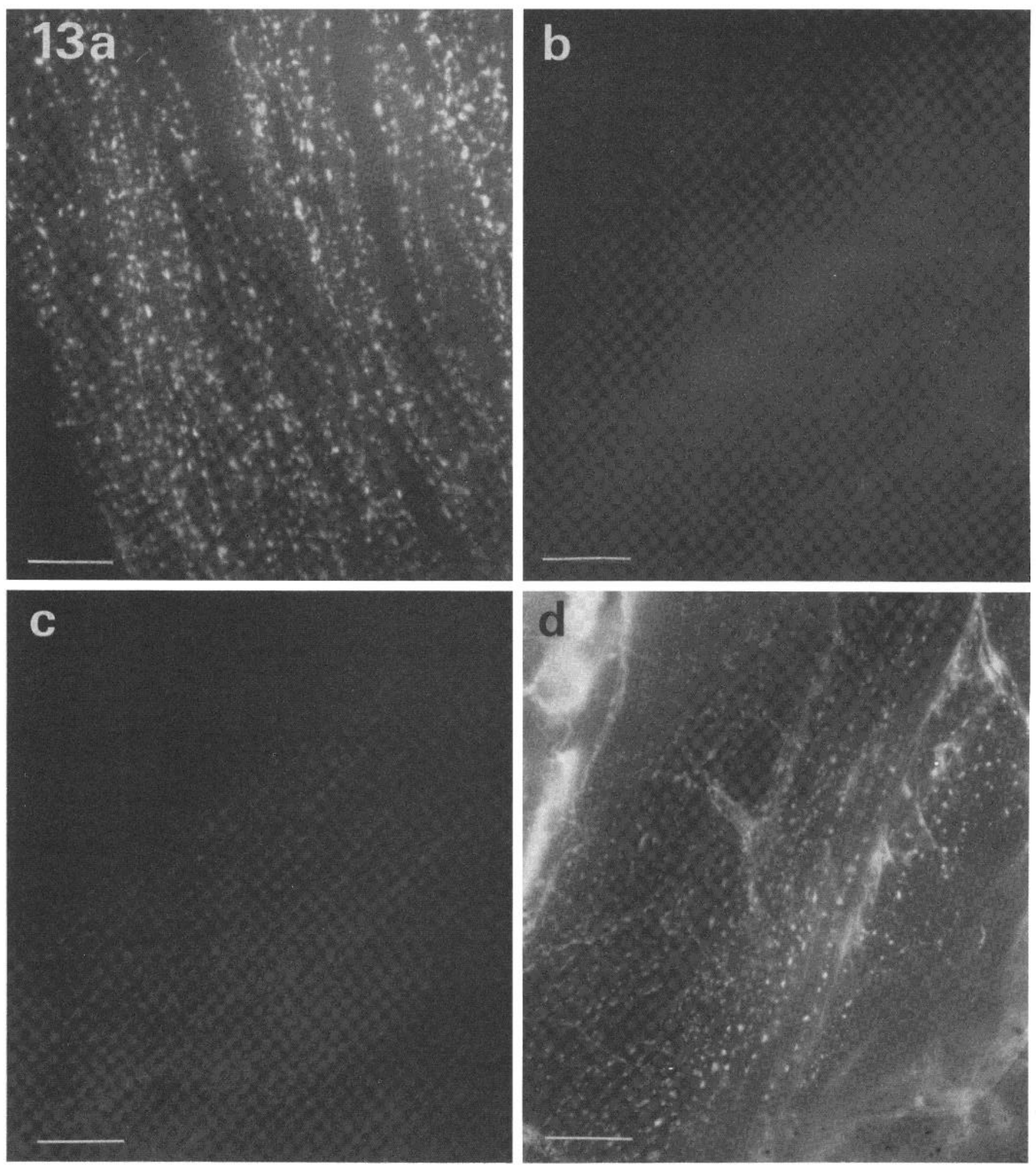

Figure 13. Absorption controls using thoracic second roots. Calibration bars $=40 \mu \mathrm{m}$. $a$, This second root was incubated in the working dilution of antiserotonin antibody. The immunoreactive plexus of fine fibers and varicosities is characteristic of thoracic second roots. $b$, Photograph of a second root that was incubated in serum pre-absorbed with a serotonin-BSA conjugate. No immunoreactivity is seen in the plexus surrounding the root. $c$, Picture of a second root that was incubated in serum pre-absorbed with serotonin. Slight immunoreactivity is seen in the second root plexus. $d$, Picture of a second root that was incubated in serum pre-absorbed with BSA. The immunoreactivity in the plexus appears normal (compare with $a$ ). 
whereas a nearly complete block of staining is seen when serum is pre-absorbed with serotonin alone (Fig. 13c). The slight fluorescence that remains in the latter case may be due to antibodies with a particularly high affinity for the serotonin-BSA conjugate and a lower affinity for free serotonin. Such antibodies might have a far greater preference for serotonin fixed to tissue than for the free serotonin used in the pre-absorption and might, therefore, bind to the tissue antigen preferentially. BSA alone (Fig. 13d) and octopamine (not shown) did not interfere with the immunofluorescence.

In a second set of experiments, we examined the specificity of staining in central ganglia with similar results. Pre-absorption with a serotonin-BSA conjugate completely blocked the fluorescence, whereas BSA alone had no effect.

5,7-Dihydroxytryptamine (5,7-DHT) injections. Livingstone et al. (1981) demonstrated that 2 to 3 weeks after adult lobsters were injected with 5,7-DHT, the endogenous serotonin content of thoracic second roots was reduced by $90 \%$ and the capacity of this region to synthesize serotonin from tryptophan by $85 \%$. 5,7-DHT treatment did not change the octopamine content of roots (which is about 10 times the serotonin content) or its rate of synthesis from precursor compounds (tyrosine or tyramine) (Livingstone et al., 1981). Therefore, using this treatment we can distinguish between serotonin immunoreactivity and any possible cross-reactivity of the antibody with octopamine. We injected immature lobsters with 5,7-DHT (see "Materials and Methods") and 2 to 4 weeks after injection, thoracic second rools were examined by immunohistochemical techniques. Two types of results were seen. Either the nerve plexuses surrounding the roots were completely depleted of fluorescence (Fig. 14a) or a few punctate spots remained that were not at all comparable to the profuse strings of endings seen in control tissues (Fig. 14b). Occasionally both kinds of results were seen in paired roots. The punctate pattern may represent a remnant of the peripheral plexus in the process of degeneration.

In central ganglia of adult animals, 5,7-DHT treatment was less effective in reducing the serotonin content (Livingstone et al., 1981). For example, the endogenous serotonin content was reduced $44 \%$ in thoracic ganglia, $52 \%$ in the subesophageal ganglion, and only $14 \%$ in the brain. The immunohistochemical results also indicate a partial depletion of serotonin in the central nervous system. The cell bodies and central fiber bundles show apparently normal staining properties, whereas neuropil regions show little or no residual fluorescence (compare Fig. $14 c$ to Fig. $4 a$ ).

\section{Discussion}

A major goal of these studics was to determine whether immunohistochemical procedures could be used to develop a reasonably complete morphological picture of the serotonin-containing system of neurons in lobsters. Such studies would, we felt, complement our prior biochemical and anatomical studies and allow us to begin a physiological analysis of this system at a cellular level.

Validity of the observed pattern of staining. The completeness and accuracy of the morphological picture presented in this article depend on: (1) the specificity for serotonin of the antibody preparations; (2) the ability of the antibodies to penetrate tissues and bind to tissue sites containing serotonin in whole mount preparations; and (3) there being sufficient levels of serotonin in cells to be revealed by the staining procedure.

We tested the first point, the specificity of the antibodies for serotonin, in several ways: (1) by inhibiting the immunohistochemical staining by pre-absorbing antisera with serotonin-conjugated antigen and with free serotonin (Fig. 13); (2) by failing to block staining by preabsorption of antisera with other amines found in the lobster nervous system; and (3) by dramatically reducing staining with procedures that reduce serotonin levels in lobsters (Fig. 14). The last test, in which animals were injected with 5,7-dihydroxytryptamine, is a particularly important control. 5,7-DHT injection does not destroy octopamine-containing nerve endings and does not reduce the levels of octopamine in the lobster nervous system (Livingstone et al., 1981), but it does abolish the staining of nerve endings by the immunohistochemical procedure. This result, and the failure to inhibit staining when sera are pre-absorbed with octopamine, indicate that the antibody preparations are not staining octopamine-containing structures. We have not, however, ruled out the possibility that indole derivatives other than serotonin might be found in certain of the stained neurons. Serotonin is metabolized in lobsters to $\beta$-alanyl and sulfate conjugates and a $\beta$-alanyl, sulfate double conjugate (Kennedy, 1977, 1978). We do not know if these or related compounds react with our antibody preparations. For the larger cells, it is possible to isolate individual cell bodies and analyze them directly for serotonin. Such studies will be a necessary part of the evidence that the stained cells actually contain serotonin.

We attempted to deal with the second point, the penetration of antibodies into tissue whole mounts, both by using immature lobsters where the ventral nerve cord is small, and by comparing the results of whole mount experiments with those where ganglia from adult and immature animals were sectioned prior to immunohistochemical processing. We noted no significant differences in the patterns of cell body staining or in the major features of ganglionic organization between sectioned and intact tissues.

In considering the final point, whether sufficient concentrations of serotonin were present in cells to be detectable by these methods, we attempted to raise serotonin levels by incubating tissues with tryptophan, serotonin (Livingstone et al, 1981), and colchicine prior to fixation. Here again we observed no differences between control and pre-incubated tissues.

These three types of control experiments and the observation that the pattern of staining of cells and their processes is highly reproducible, support the validity of the morphological picture of serotonin-like immunoreactivity that we report in this paper.

Serotonin staining in crustaceans by histofluorescence methods: comparisons with the immunohistochemical results. Serotonin-containing structures have been identified previously in a variety of crustaceans using the Falck-Hillarp histofluorescence technique (Falck et al., 1962) (crayfish: Astacus astacus, Elofsson et al., 1966; crab: Carcinus maenas, Libinia emarginata, 

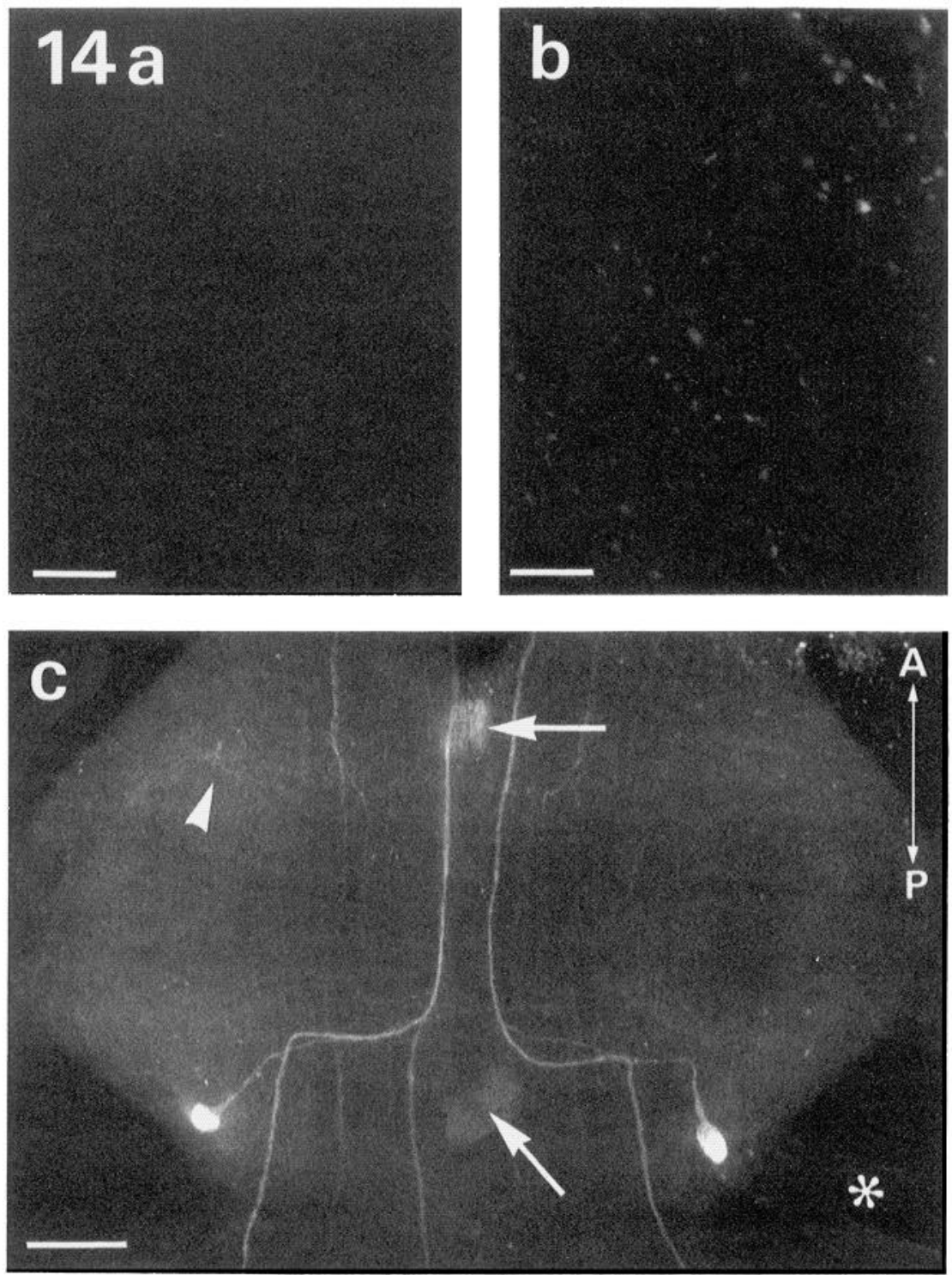

Figure 14. Thoracic second roots and a 4th thoracic ganglion from lobsters treated with 5,7-dihydroxytryptamine. $a$ and $b$, In these photographs, the plexus that normally surrounds each thoracic second root contains little $(b)$ or no $(a)$ immunoreactivity. Calibration bar $=20 \mu \mathrm{m}$. c, Arrowhead at left points to a faint remnant of neuropil in this 4th thoracic ganglion. The lateral neuropil on the right side is completely absent (compare to Fig. $4 a$ ). The asterisk is over one second root that is faintly immunoreactive. Arrows point to two vacuole-like structures that appear in some ganglia following 5,7-dihydroxytryptamine treatment. These are probably not cell bodies because they show no neuronal processes. Calibration bar $=300 \mu \mathrm{m}$.

Libinia dubia, Cancer irroratus, Cancer borealis, Car. disoma guanhumi, Cooke and Goldstone, 1970; Goldstone and Cooke, 1971; lobster: Panulirus interruptus, Homarus vulgaris, and Homarus americanus, Kushner and Maynard, 1977; Osborne and Dando, 1970). While these earlier studies have provided valuable information on the existence of presumptive serotonin-containing neurons in crustacean nervous tissue, our studies show over an order of magnitude higher numbers of likely serotonergic neurons. Species differences might partially account for this discrepancy. What is more likely, however, is that with crustacean tissues, particularly marine crustaceans, immunohistochemical methods yield more reliable results. Other authors have pointed out some major problems in using histofluorescence techniques for serotonin: for example, the yellow fluorescence charac- teristic of serotonin fades rapidly, making thorough examination of tissues difficult (Fuxe and Jonsson, 1967); the often subtle yellow fluorescence can be obscured by the presence of a much more stable green fluorescence characteristic of catecholamines (Fuxe and Jonsson, 1967; Kushner and Maynard, 1977; Parent, 1981); and with marine invertebrates, freeze drying of tissues often yields very poor tissue preservation (for discussion, see Goldstone and Cooke, 1971). Such difficulties are not encountered with the immunohistochemical methods: tissues are adequately preserved by fixation, at least for light microscopy; the antibodies seem to be sensitive and specific for serotonin; and the fluorescence is relatively stable for weeks if tissues are stored at $4^{\circ} \mathrm{C}$. Thus far we have not been able to show homology with the Homarus immunoreactive cells and the serotonergic neurons iden- 
tified previously by the histofluorescence techniques. This is because the organization of the ganglia of the species involved is often different (e.g., fused ganglia) or because the published figures do not provide enough landmarks for comparison.

Cell bodies and their projections in the ventral nerve cord. The majority of the approximately 100 cell bodies that show serotonin immunoreactivity in the ventral nerve cord are small and their axonal processes are too fine to trace visually. We have, however, been able to follow the major projections of the larger cell bodies in the thoracic ganglia and of the pair of large cells in the 1st abdominal ganglion. Several features of these projections raise interesting physiological possibilities. For example, while stained cells may have small arborizations of dendrites or axons in the same ganglion as their soma, the principal projections of the large cells are interganglionic. No major branches of these neurons project into the roots of the same ganglion in which the cell body appears. Instead cells send axons to join one of the three fiber bundles that traverse much of the length of the ventral nerve cord (Figs. 3 and 4). Projections from serotonin-immunoreactive cell bodies may travel through two or more ganglia before reaching their final terminations, they may have multiple targets along their route, and within target areas they may arborize extensively (as in the thoracic second root nerve plexuses). A similar structural organization is seen in serotonergic systems of molluscs and vertebrates. The processes of serotonergic cells in these systems are extremely widespread and highly branched (Steinbusch and Nieuwenhuys, 1979; Van der Kooy and Kuypers, 1979; Kupfermann and Weiss, 1981; Parent, 1981). Consistent with extensive arborizations of these cells are the very large cell body sizes seen in neurons of the 4th and 5th thoracic and the 1 st abdominal ganglia. These neurons are among the largest found in lobsters. The large cell body size also is typical of many invertebrate serotonergic neurons. For example, the serotonin-containing Retzius cells of the leech (50 to $80 \mu \mathrm{m}$ diameter) and metacerebral cells of molluses (150 to $300 \mu \mathrm{m}$ diameter) are among the largest neurons in the nervous systems of those animals (Rude et al., 1969; Coltrell and Osborne, 1970; Senseman and Gelperin, 1974; Kupfermann and Weiss, 1981). It is also of interest that in the 1st, 5 th, and 6 th abdominal ganglia we have observed unpaired cells showing serotonin-like immunoreactivity. With few exceptions, most lobster neurons that have been mapped in central ganglia are paired (Otsuka et al., 1967; but see Muramoto, 1977). Unpaired octopamine-containing cells have been found in certain insect central nervous systems (Evans and O'Shea, 1977; Hoyle, 1974, 1975, 1978). These cells are known to serve a neuromodulatory role in adult animals (O'Shea and Evans, 1979). The functional activities of the unpaired cells in lobsters remain to be explored.

Origins of the thoracic second root plexus of serotonergic endings. Our earlier studies showed that serotonin was found, synthesized, and released at two locations along lobster thoracic second roots. In agreement with these results we now observe immunohistochemical staining of a dense plexus of neuronal fibers and varicosities at these sites. At the ultrastructural level the pre- vious studies identified four morphologically distinguishable types of nerve endings in these regions, one of which was shown to be associated with serotonin by electronmicroscopic autoradiography (Livingstone et al., 1981). A confirmation of this result by immunohistochemistry at the electron microscopic level remains to be done.

A particular benefit of the present studies was that we could trace some of the axons that form the second root plexuses to their origins at central neurons or central neuropil regions. A clear connection was seen between the paired cells of the 1st abdominal ganglion and processes that project out the second roots of the 4 th, and second and third roots of the 5th thoracic ganglia. In the second roots of more anterior thoracic ganglia, nerve processes that originate at the MFBs form the nerve plexuses (see Fig. 9), but we have not traced these processes to their cell bodies of origin. One of these processes, however, originates from a very large axon in the MFB. We expect that this is the axon of one of the large paired cell bodies of the 5 th thoracic or 1st abdominal ganglia. Since at present we have no evidence that the immunoreactive cells of thoracic ganglia 1 lo 4 send projections either into the MFBs or out the thoracic second roots, it may be that all the second roots receive inputs originating from the 5th thoracic and 1st abdominal cell bodies. For this reason, we expect these two pairs of central neurons to be very important in our understanding of the functioning of the thoracic second root system. Clear conneclions have also been seen between central neuropil regions and processes entering the thoracic second roots (see Fig. 9). These neuropil regions are connected with LFB fibers in each ganglion, but we have not been able to trace these fibers back to their cells of origin.

Earlier studies from this laboratory revealed that the firing of cell bodies in the thoracic second roots is inhibited by serotonin (Konishi and Kravitz, 1978). Since the serotonin-immunoreactive varicosities forming second root plexuses are in close proximity to these cells, it is possible that the central neurons from which these plexuses originate control the firing of the root cells via local release of serotonin. If this is so, the peripheral serotonergic nerve plexuses might serve both as the source of serotonin that functions as a circulating neurohormone through direct release of the amine into the hemolymph and also govern the firing, and thereby the release, of the neurosecretory materials (as yet unidentified) associated with the peripheral neurosecretory neurons.

Physiological actions of serotonin on peripheral and central tissues in lobsters. Our earlier studies and those of other investigators have identified effects of this amine on various peripheral tissues: neuromuscular preparations (Weiss et al., 1978; Glusman and Kravitz, 1982); heart (Cooke, 1966; Cooke and Hartline, 1975); scaphagnothite (Berlind, 1977). These tissues are very sensitive to serotonin: for example, in some neuromuscular preparations, concentrations as low as $5 \times 10^{-9} \mathrm{M}$ increase transmitter release from excitatory and inhibitory nerve endings and enhance contractions in muscle fibers (Glusman and Kravitz, 1982). Since neuromuscular preparations and many other responsive peripheral tissues contain no measurable serotonin, the amine may act on 
many of these tissues in vivo as a neurohormone carried in the hemolymph. Measurements of serotonin levels in lobster hemolymph support this possibility: the amine circulates at close to its physiologically effective concentration $\left(10^{-9} \mathrm{M}\right.$ range). The circulating serotonin probably comes from the dense plexuses of nerve endings found along the thoracic second nerve roots (see above), and at least some of these release sites originate from identified central cell bodies. We now have an opportunity to study the properties of these serotonin-releasing cells directly using intracellular techniques.

In addition to its actions on peripheral tissues, more recent studies have shown that serotonin affects lobster central ganglia as well (Livingstone et al., 1980; D. Glanzman and F. Krasne, personal communication). Injecting serotonin into freely moving animals causes a characteristic flexed posture (Livingstone et al., 1980). Studies with isolated central ganglia suggest that the posture is produced by a serotonin-triggered motor program consisting of coordinated firing of the excitatory and inhibitory neurons innervating postural skeletal muscles (Livingstone et al., 1980). In contrast to the peripheral effects, however, the central actions require concentrations of serotonin orders of magnitude higher than those found circulating in the hemolymph. Such concentrations $\left(10^{-5}\right.$ to $10^{-6} \mathrm{M}$ ) would not be reached in the hemolymph of lobsters even if animals liberated their entire store of serotonin. Therefore, circulating serotonin is not likely to be responsible for the amine-induced postural changes. We do not know why such high concentrations of serotonin are necessary to produce central actions. One possibility is that sensitive sites in central ganglia are not easily reached by serotonin due to permeability barriers; another possibility is that central serotonin receptors respond only to high concentrations of the amine and ignore low concentrations. If serotonin was released from central synaptic sites where the local concentration was high, both of these problems would be circumvented. The presence of immunoreactive neuropil regions in central ganglia (shown in Figs. 4, 8, 9, and 12) suggests that synaptic sites capable of releasing serotonin might exist in the ventral nerve cord, in addition to the peripheral hormonal release already documented (Sullivan et al., 1977; Livingstone et al., 1981). Electron microscopic examination of the immunoreactive processes within these neuropil regions and direct release experiments, however, will be needed before we can say with any surety that central serotonergic synapses actually exist in the lobster ventral nerve cord.

The morphological studies described in this paper are steps toward unraveling the function of serotonin in lobsters. We are impressed by the extensive and elaborate distribution of this amine, as well as by the diversity of its physiological effects. The immunological methods have identified many neurons throughout the lobster nervous system that are likely to contain serotonin and have set the stage for physiological experiments dealing with the activation and consequences of activation of these cells. Ultimately, through a combined physiological, biochemical, and anatomical approach, we hope to learn what factors cause serotonin release, both centrally and peripherally, and what consequences the release of this amine has on the behavior of the animal.

\section{References}

Battelle, B. A., and F. A. Kravitz (1978) Targets of octopamine action in the lobster: Cyclic nucleotide changes and physiological effects in haemolymph, heart, and exoskeletal muscle. J. Pharmacol. Exp. Ther. 205: 438-448.

Berlind, A. (1977) Neurohumoral and reflex control of scaphognathite beating in the crab Carcinus maenus. J. Comp. Physiol. 116: 77-90.

Bishop, C. A., and M. O'Shea (1982) Neuropeptide proctolin (H-Arg-Tyr-Leu-Pro-Thr-OH): Immunocytochemical mapping of neurons in the central nervous system of the cockroach. J. Comp. Neurol. 207: 223-238.

Cooke, I. M. (1966) The sites of action of pericardial organ extract and 5-hydroxytryptamine in the decapod crustacean heart. Am. Zool. 6: 107-121.

Cooke, I. M., and M. W. Goldstone (1970) Fluorescence localization of monoamines in crab neurosecretory structures. J. Exp. Biol. 53: 651-668.

Cooke, I. M., and D. K. Hartline (1975) Neurohormonal alteration of intcgrative propertics of the cardiac ganglion of the lobster Homarus americanus. J. Exp. Biol. 63: 33-52.

Cottrell, G. A., and N. N. Osborne (1970) Subcellular localization of serotonin in an identified serotonin-containing neurone. Nature 225: 470-472.

Dudel, J. (1965) Facilatatory effects of 5-hydroxytryptamine on the crayfish neuromuscular junction. Naunyn-Schmiedebergs Arch. Exp. Pathol. Pharmacol. 249: 515-528.

Elofsson, R., T. Kauri, S.-O. Nielsen, and J. O. Stromberg (1966) Localization of monoaminergic neurons in the central nervous system of Astacus astacus Linné (Crustacea). Z. Zellforsch. 74: 464-473.

Evans, P. D., E. A. Kravitz, B. R. Talamo, and B. G. Wallace (1976) The association of octopamine with specific neurons along lobster nerve trunks. J. Physiol. (Lond.) 262: 51-70.

Evans, P. D., and M. O'Shea (1977) The identification of an octopaminergic neurone and the modulation of a myogenic rhythm in the locust. J. Exp. Biol. 73: 235-260.

Falck, B., N.-A. Hillarp, G. Thieme, and A. Torp (1962) Fluorescence of catecholamines and related compounds condensed with formaldehyde. J. Histochem. Cytochem. 10:348354.

Florey, F., and E. Florey (1954) Uber die mogliche Bedeutung von Enteramin (5-oxytryptamine) als nervoser Akterrssubstanz bei cephalopoden und dekapoden crustacean. Z. Naturforsch. 96 : $58-68$.

Florey, E., and M. Rathmayer (1978) The effects of octopamine and other amines on the heart and on neuromuscular transmission in dccapod crustaceans: Further evidence for a role as a neurohormone. Comp. Biochem. Physiol, 61C: 229-237.

Fuxe, K., and G. Jonsson (1967) A modification of the histochemical fluorescence method for the improved localization of 5-hydroxytryptamine. Histochemie 11: 161-166.

Glusman, S., and E. A. Kravitz (1982) The action of serotonin on excitatory nerve terminals in lobster nerve-muscle preparations. J. Physiol. (Lond.) 325: 223-241.

Goldstone, M. W., and I. M. Cooke (1971) Histochemical localization of monoamines in the crab central nervous system. $\mathrm{Z}$. Zellforsch. 116: 7-19.

Grundfest, H., and J. P. Reuben (1961) Neuromuscular synaptic activity in lobster. In Nervous Inhibition, E. Florey, ed., pp. 92-104, Pergamon Press, New York.

Hökfelt, T., K. Fuxe, and M. Goldstein (1975) Applications of immunohistochemistry to studies on monoamine cell systems with special reference to nervous tissues. Ann. N. Y. Acad. Sci. 254: 407-437.

Hoyle, G. (1974) A function for neurons (DUM) neurosecretory on skeletal muscle of insects. J. Exp. Zool. 189: 401-406.

Hoyle, G. (1975) Evidence that insect dorsal unpaired median 
(DUM) neurons are octoparninergic. J. Exp. Zool. 193: 425431.

Hoyle, G. (1978) The dorsal, unpaired, median neurons of the locust metathoracic ganglion. J. Neurobiol. 9: 43-57.

Kennedy, M. B. (1977) Amine metabolism: A different pathway in lobsters. Soc. Neurosci. Abstr. 3: 792.

Kennedy, M. B. (1978) Products of biogenic amine metabolism in the lobster: Sulfate conjugates. J. Neurochem. 30: 315-320.

Konishi, S., and E. A. Kravitz (1978) The physiological properties of amine-containing neurones in the lobster nervous system. J. Physiol (Lond.) 279: 215-229.

Kravitz, E. A., S. Glusman, R. M. Harris-Warrick, M. S. Livingstone, T. Schwarz, and M. F. Goy (1980) Amines and a peptide as neurohormones in lobsters: Action on neuromuscular preparations and preliminary behavioral studies. J. Exp. Biol. 89: 159-175.

Kupfermann, I., and K. R. Weiss (1981) The role of serotonin in arousal of feeding behavior of Aplysia. In Serotonin Neurotransmission and Behavior, B. Jacob and A. Gelperin, eds., pp. 255-287, MIT Press, Cambridge, MA.

Kushner, P. D., and F. A. Maynard (1977) Localization of monoamine fluorescence in the stomatogastric nervous system of lobsters. Brain Res. 129: 13-28.

Livingstone, M. S., R. M. Harris-Warrick, and E. A. Kravitz (1980) Serotonin and octopamine produce opposite postures in lobsters. Science (N. Y.) 208: 76-79.

Livingstone, M. S., S. F. Schaeffer, and E. A. Kravitz (1981) Biochemistry and ultrastructure of serotonergic nerve endings in the lobster: Serotonin and octopamine are contained in different nerve endings. J. Neurobiol. 12: 27-54.

Maynard, D. M., and J. H. Welsh (1959) Neurohormones of the pericardial organs of brachyuran Crustacea. J. Physiol. (Lond.) 149: 215-227.

McLean, I. W., and P. K. Nakane (1974) Periodate-lysine-paraformaldehyde fixative. A new fixative for immunelectron microscopy. J. Histochem. Cytochem. 22: 1077.

Miller, M. W., and R. E. Sullivan (1981) Some effects of proctolin on the cardiac ganglion of the Maine lobster, Homarus americanus (Milne Edwards). J. Neurobiol. 12: 629-639.

Muramoto, A. (1977) Neural control of rhythmic anal contraction in the crayfish. Comp. Biochem. Physiol. 56A: 551-557.

Osborne, N. N., and M. R. Dando (1970) Monoamines in the stomatogastric ganglion of the lobster Homarus vulgaris. Comp. Biochem. Physiol. 32: 327-331.

O'Shea, M., and P. D. Evans (1979) Potentiation of neuromuscular transmission by an octopaminergic neurone in the lo- cust. J. Exp. Biol. 79: 169-190.

Otsuka, M., E. A. Kravitz, and D. D. Potter (1967) Physiological and chemical architecture of a lobster ganglion with particular reference to gamma-aminobutyrate and glutamate. J. Neurophysiol. 30: 725-752.

Parent, A. (1981) The anatomy of serotonin-containing neurons across phylogeny In Serotonin Neurotransmission and Behavior, B. Jacobs and A. Gelperin, eds., pp. 3-34, MIT Press, Cambridge, MA.

Rude, S., R. E. Coggeshall, and L. S. Van Orden, III (1969) Chemical and ultrastructural identification of 5-hydroxytryptamine in an identified neuron. J. Cell Biol. 41: 832-854.

Schwarz, T. L., R. M. Harris-Warrick, S. Glusman, and E. A. Kravitz (1980) A peptide action in a lobster neuromuscular preparation. J. Neurobiol. 11: 623-628.

Schwarz, T. L., G. Lee, and E. A. Kravitz (1981) Proctolin-like immunoreactivity in the nervous system of the lobster Homarus americanus. Soc. Neurosci. Abstr. 7: 253.

Senseman, D., and A. Gelperin (1974) Comparative aspects of the morphology and physiology of a single identifiable neuron in Helix aspersa, Limax maximus, and Agriolimax californica. Malacolog. Rev. 7: 51-52.

Steinbusch, H. W. M., and R. Nieuwenhuys (1979) Serotonergic neuron systems in the brain of the lamprey, Lampetra fluviatilis (abstr.) Anat. Rec. 193: 693.

Steinbusch, H. W. M., A. A. J. Verhofstad, and H. W. T. Joosten (1978) Localization of serotonin in the central nervous system by immunohistochemistry: Description of a specific and sensitive technique and some applications. Neuruscience 3 : 811819.

Sullivan, R. E. (1979) A proctolin-like peptide in crab pericardial organs. J. Exp. Zool. 210: 543-552.

Sullivan R. E., and D. L. Barker (1975) Octopamine increases cyclic AMP content of crustacean ganglia and cardiac muscle. Soc. Neurosci. Abstr. 1: 394.

Sullivan, R. E., B. J. Friend, and D. L. Barker (1977) Structure and function of spiny lobster ligamental nerve plexuses: Evidence for synthesis, storage, and secretion of biogenic amines. J. Neurobiol. 8: 581-605.

Van der Kooy, D., and H. G. J. M. Kuypers (1979) Fluorescent retrograde double labelling: Axonal branching in the ascending raphe and nigral projections. Science 204: 873-875.

Weiss, K. R., J. L. Cohen, and I. Kupfermann (1978) Modulatory control of buccal musculature by a serotonergic neuron (metacerebral cell) in Aplysia. J. Neurophysiol. 41: 181-203. 